\title{
The Ideological Roots of Institutional Change*
}

\author{
Murat Iyigun, University of Colorado Jared Rubin, Chapman University
}

April 2017

\begin{abstract}
Why do some societies fail to adopt more efficient institutions in response to changing economic conditions? And why do such conditions sometimes generate ideological backlashes and at other times lead to transformative sociopolitical movements? We propose an explanation that highlights the interplay-or lack thereof-between new technologies, ideologies, and institutions. When new technologies emerge, uncertainty results from a lack of understanding how the technology will fit with prevailing ideologies and institutions. This uncertainty discourages investment in institutions and the cultural capital necessary to take advantage of new technologies. Accordingly, increased uncertainty during times of rapid technological change may generate an ideological backlash that puts a higher premium on traditional values. We apply the theory to numerous historical episodes, including Ottoman reform initiatives, the Japanese Tokugawa reforms and Meiji Restoration, and the Tongzhi Restoration in Qing China.
\end{abstract}

JEL Classifications: D02, N40, N70, O33, O38, O43, Z10

Keywords: Ideology, Institutions, Conservatism, Beliefs, Institutional Change, Technological Change, Uncertainty

${ }^{*}$ We are grateful for comments received from the participants at workshops at Stanford (AALIMS), Chapman (ASREC), University of Colorado, the Washington Area Economic History Seminar and the 2017 AEA Meetings. Lee Alston, Cihan Artunç, Lisa Blaydes, Jean-Paul Carvalho, Avner Greif, Saumitra Jha, Asim Khwaja, Mark Koyama, Timur Kuran, Debin Ma, Tom Pepinsky, Eitan Regev, and Tuan Hwee Sng provided extremely useful comments. All errors are ours. 


\section{Introduction}

Why do some societies fail to adopt political or economic institutions that are commensurate with a changing technological and economic landscape? History is littered with instances of societies cognizant of, but failing to adopt, advanced market structures, legal codes, and organizational forms. For instance, Kuran (2011) notes that European commercial law was widely used and permitted in the Ottoman Empire, but only for European merchants. The various European legal codes permitted much more complex financial transactions than what was available to Ottoman merchants. Why did the Ottomans not adopt such obviously beneficial institutions? Likewise, the Qing Empire famously turned inward in the 17th and 18th centuries, just as contact with the West made it obvious to casual observers that Western organizational forms were far superior. In both cases, the stagnant society missed out on a transition to a more efficient economy. Given the stakes involved, why do institutional calcifications ever occur?

Even more curiously, the rejection of more efficient institutions against the backdrop of rapidly changing economic conditions is frequently coupled with a "conservative revival". By "conservative", we simply mean a situation in which traditional ideology dominates discourse. By "ideology", we mean the shared cognitive rules that people within a society use to interpret the world around them (North 1981; Greif and Mokyr 2016). Therefore, a "conservative revival" is a situation in which a society interprets the world around them through the lens of traditional values that "worked well in the past," even if what made the society successful in the past is poorly understood. Contemporary examples of such a backlash abound, including the widely expressed desire among some segments of the U.S. population to "return to the 1950s" and the ubiquitous Middle Eastern trope of "returning to the Golden Age of Islam."

Such traditional values are often incompatible with advanced technologies and institutions because they were formed when the technological and institutional environment was drastically different. In the Ottoman case, after it was clear that Western Europe had far surpassed the Empire, it was still true that "even the most intelligent and perceptive of Ottoman reformers at this time adhered to the basic premise that the Ottoman system was far superior to anything that the infidel might develop" (Shaw 1976, p. 175). Other examples include the famed "social decay" of the late Roman Empire, the inward turns of Qing China and Shogunate Japan in response to contact with Europe, and British unpreparedness for World War I. These examples are all reflective of societies built on ideologies associated with past glory but ill-suited for a much changed world. Why do such conservative sociopolitical movements so often go hand-in-hand with institutional stagnation?

This paper presents a model that jointly addresses both of these puzzles by endogenizing institutional change and ideological evolution. We employ an overlapping generations model where technology is subject to outside productivity shocks. Alternatively, one can entertain the notion that the society is not on the technological frontier but, instead, is exposed to a new technology. ${ }^{1}$ The primary source of risk associated with new technologies in our model is a lack of understanding how the technology will fit with the prevailing ideologies and institutions. In other words, there is an inherent risk associated with how a society's cognitive rules will "fit" with the new technology.

In our model, ideological beliefs are passed down from parent to child as in Bisin and Verdier (2001).

\footnotetext{
${ }^{1}$ We ignore the possibility that institutions are not adopted because they are contrary to the interest of the politically powerful. This is a widely accepted answer in the literature on technology non-adoption (Acemoglu and Robinson 2000, 2006; Chaudry and Garner 2007; Cosgel et al. 2012). We ignore this possibility not because it is wrong, but because it has already received significant attention (see, e.g., Kuran 2011, Koyama et al. 2016) while only accounting for certain episodes of adoption failure. Industrialization provides an instructive counter-example. Although some vested interests would have been harmed by the adoption of industrial technologies and the institutions that support an industrial economy, by the turn of the 20th century the benefits of industrialization were obvious. Yet, most of the world's population lived in non-industrialized economies.
} 
Alternatively, parents can exert costly effort to provide their children with an education that can equip them with the cognitive capacity to assess the production environment through a potentially more objective lens - one that is more compatible with future technologies than their own ideology. ${ }^{2}$ Finally, there is a selfinterested political ruler who maximizes tax revenue over the infinite planning horizon. This ruler can invest in improving the society's institutions to better accommodate technology, although institutional change is costly. $^{3}$

Our model provides two primary insights. First, there is an interplay between technological risk on the one hand and ideological as well as institutional evolution on the other. The degree of risk inherent in newly-adopted technologies could drive individuals to emphasize the intergenerational transmission of their prevailing ideologies at the expense of investing in a new cognitive framework for their children. This occurs despite the fact that education is the channel through which ideologies would evolve to remain compatible with new technologies. In turn, political rulers fail to adopt "better" and more efficient institutions even if - and despite the fact that — doing so would be a first-order economic improvement. The riskier are the new technologies, the more likely that ideologies and institutions would stagnate due to the fact that individuals are risk averse. In fact, even when adopting "better" institutions is unambiguously a first-order improvement for the society, as it is under our formulation, both the existing (backward) state of economic development and the society's ideological beliefs would be unlikely to change despite the fact that a change in either ideology or institutions might trigger a positive response in the other. But this is precisely the point; in an uncertain world, such change is too risky and thus does not happen in equilibrium. In other words, conservatism is an outcome; it is not a root cause of failure to adopt more efficient institutions and technologies. ${ }^{4}$

Our second insight follows from the fact that technological progress and uncertainty about new technologies often arise together. New technologies can represent a fundamentally new way of producing or consuming at the expense of what one knows and is comfortable with. Moreover, new technologies - especially those with a foreign origin - may not be compatible with the existing resource, institutional, or ideological bases. Our model indicates that when uncertainty dominates, institutions and ideologies are unlikely to respond to technological change. Hence, a "catch-22" arises where ideologies do not evolve, and as a consequence institutions fail to upgrade. Meanwhile, it is precisely because institutions do not evolve that ideologies stagnate. In such a case, the conservative backlash is all the more pronounced as the traditional ideology is ascribed to in spite of a rapidly changing world ill-suited for old ideologies.

\footnotetext{
${ }^{2}$ We use the term "education" in a stylized and informal sense. In fact, and as we shall elaborate further, formal education may not be the channel through which future workers acquire skills that enable them to more objectively comprehend the production environment in which they will be economically active. Alternatively, the channel of ideological transmission could well be a public education system that is used to propagate a political regime's (potentially self-serving and preserving) ideological and political doctrines. In that case, schooling could be free but time spent at school would instill and propagate the existing state ideologies and political doctrines. In order to escape such indoctrination, parents would need to invest time or resources in a form of private education that would provide the offspring with the cognitive skills necessary to assess the technological and productive environment more objectively. We revisit this issue in Section 2.2.

${ }^{3}$ In making his optimal choice, the ruler may or may not take as given his subjects' ideological beliefs. In Section 4 , we elaborate on this point and also look at the situation in which the ruling political classes can use the public education system to propagate ideological beliefs that are consistent with their self interest.

${ }^{4}$ For more on conservatism as an outcome of institutional environments, see Rubin $(2011,2017)$. There is a significant body of literature in psychology which indicates that individuals with heightened sense of risk and lower risk tolerance tend to be more conservative (Jost 2006; Haidt 2012). As stated by Laber-Warren (2012), for instance: "Psychologists have found that conservatives are fundamentally more anxious than liberals, which may be why they typically desire stability, structure and clear answers even to complicated questions. 'Conservatism, apparently, helps to protect people against some of the natural difficulties of living." This noted, we differ from the existing studies in psychology in that we do not take as given individuals being conservative or liberal. Indeed, our main contribution to the related literatures in political economy, sociology, and psychology is that we attempt to identify the economic conditions in which individuals could become more conservative or liberal.
} 
This paper is not the first to suggest an interaction between culture and institutions. ${ }^{5}$ Other works that are particularly relevant to our hypothesis are those that attempt to explain why culture persists in spite of changing economic circumstances. Guiso et al. (2016) show the extremely long-term persistence of civic capital in cities that attained independence in the medieval period. They argue that the cultural transmission of self-efficacy beliefs is the cause of the persistence they find. Greif $(1994,2006)$ argues that the individual/collectivist cultural distinction directly influenced the distinct types of economic institutions of the (individualistic) Italian city-states and the (collectivist) Maghribi traders, and that these institutions persisted well beyond the conditions under which they were an optimal response. ${ }^{6}$ Giuliano and Nunn (2016) show that, consistent with the anthropology literature, societies tend to emphasize traditional values more in relatively stable and predictable environments; just like in our model, uncertainty and conservative values are negatively correlated cross sectionally and over time. Nunn and de la Sierra (2017) show that cultural beliefs ill-suited for modernity (e.g., beliefs in magic) may be Pareto efficient for the group, although not the individual, under certain conditions. Alston et al. (2016) provide an insightful example from Brazil in the late twentieth and early twenty-first centuries of how culture is endogenous to beliefs and institutions and how decisive moments can push society to one belief-institution equilibrium or another. ${ }^{7}$

The recent theory paper most similar to ours is Bisin and Verdier (2015), who also study the coevolution of institutions and culture. They argue that culture and institutions may act as complements or substitutes. In the former (latter) case, the interaction of the two strengthens (weakens) the equilibrium patterns and institutions are more (less) likely to produce their desired effect. ${ }^{8}$ Acemoglu and Jackson (2016) investigate the coevolution of social norms and the enforcement of codified laws. They argue that laws which are in conflict with prevailing social norms may be counterproductive; it is only when such laws are gradually introduced that they are effective. Both Bisin and Verdier (2015) and Acemoglu and Jackson (2016) provide valuable insights into the coevolution of institutions and culture. But one important aspect of this coevolution which both papers fail to adequately address is why institutions fail to update in the face of changes which make the prevailing institutions and ideological beliefs obsolete. ${ }^{9}$ This is hardly a trivial issue; failure to adopt modern institutions is a primary reason for the failure of laggard economies to converge with the leaders

\footnotetext{
${ }^{5}$ For overviews of recent developments of various aspects of this literature, see Guiso et al. (2006), Nunn (2012), Spolaore and Wacziarg (2013), Algan and Cahuc (2013), Alesina and Giuliano (2015), and Gershman (2016).

${ }^{6}$ By contrast, Greif, Iyigun and Sasson (2012) and Greif and Iyigun (2013) claim that cultural differences in risk sharing and management could go some way in explaining the historically divergent economic paths of China versus England. Gorodnichenko and Roland $(2011,2016)$ argue that this cultural distinction is at the root of differences in innovation across societies.

${ }^{7}$ There are many other important works on the interaction of culture and institutions. For instance, Putnam (1993) shows how different cultural characteristics related to social capital in northern and southern Italy—remnants of the medieval period-affected institutional changes in the 20th century. Tabellini (2010) provides empirical evidence that numerous cultural attributes-many of which are strong predictors of modern economic well-being - are consequences of a society's institutional past. Tabellini (2008) argues that "generalized morality" evolves from a society's institutional past and is related to well-functioning institutions in the present. Greif and Tabellini (2017) build on these insights, showing how kin-based cultures coevolve with clan-based enforcement institutions while "generalized morality" cultures coevolve with more corporate, group-independent institutional forms. Alesina et al. (2013) study the link between traditional plough agriculture (and its associated institutions) and the evolution of gender norms. Lowes et al. (2017) find that descendants of the Central African Kuba kingdom, which historically had more formal institutions than its neighbors, have weaker rule-following norms today. For more economic insights into the "long hand" of culture, see Giuliano (2007), Guiso et al. (2008), Nunn and Wantchekon (2011), Voigtländer and Voth (2012), Jha (2013), Grosfeld et al. (2013), Becker et al. (2016), Buggle (2016), and Rubin and Karaja (2017).

${ }^{8}$ Greif and Tadelis (2010) provide a model of institutional and cultural evolution where people "hide" their culture in the face of oppressive institutions. This paper differs from ours in that we seek to understand why culture and institutions do not co-evolve together despite favorable circumstances, whereas Greif and Tadelis focus on a situation where culture does not evolve in spite of institutional evolution.

${ }^{9}$ The model in Bisin and Verdier (2015) has institutional design built into it. It therefore does not address how institutions and culture coevolve in response to a shock that changes the conditions under which the institutions were originally designed. An implication of Acemoglu and Jackson (2016) is that such a shock could be accounted for by gradual institutional change. But there are numerous counter-examples discussed in this paper that challenge such processes happening in economic history. An alternative approach is therefore needed to account for these observed phenomena.
} 
(North 1981; Greif 2006; Kuran 2011; Rubin 2017). Our paper addresses precisely this issue. Moreover, it is the first example of its kind to link the interplay among technologies, culture, and institutions on the one hand with sociopolitical movements that hinder or aid change on the other.

After we present our baseline theory, we turn to a discussion of five historical cases that associate well with our model. These include the historiography of the Ottoman Empire where reformist movements spanned from clearly traditionalist, starting in the early-17th century and spanning through 18th century, to the unabashedly modernizing Tanzimat Reform era during the second half of the 19th century; the Japanese experience, ranging from the final century and a half of the Tokugawa Shogunate, when the three salient reformist movements had clear and specific traditionalist goals, to the Meiji Restoration in the middle of the 19th century, which was driven in large part by an acknowledgment that the traditional organization of Japanese society was inadequate to deal with the modern challenges of adopting Western technologies and methods; and, finally, a discussion of the Tongzhi Restoration in Qing China which presents a particularly illuminating example of a "conservative revival" in response to foreign technological and institutional innovations.

The rest of our paper proceeds as follows. Section 2 lays out the model. Section 3 provides some historical examples pertinent to our model. Section 4 reconsiders the model with education as the indoctrinating medium. Section 5 offers some concluding thoughts and discusses paths of future research direction.

\section{The Model}

\subsection{Setup}

Consider an infinite-horizon, overlapping generations economy with one representative young agent, one representative old agent, and a Ruler $(R)$ in each period. ${ }^{10}$ Each agent lives for two periods (one young and one old) except for the Ruler, who is infinitely-lived. ${ }^{11}$ Old agents are productive but young agents are not. Old agents have preferences over their own consumption and the consumption possibilities of their children, while the Ruler has preferences over current and future tax revenue. ${ }^{12}$

Old agents are endowed with one unit of time, which they can only spend on labor $\left(\ell_{t} \in[0,1]\right)$. The output produced by their labor is $y_{t}=A_{t} \ell_{t}$, where $A_{t}$ is a productivity parameter. $A_{t}$ has three components: a technology component $\left(G_{t}\right)$, the economy's institutions $\left(I_{t} \in \mathbb{R}^{+}\right)$, and the workers' (old agents') ideology $\left(D_{t}^{o} \in \mathbb{R}^{+}\right)$. We explain the determinants of each of these factors in turn.

First, the realization of $G_{t}$ is comprised of a deterministic component and a positive or negative shock such that, with probability $p \in[0,1]$, the effective level of technology is above its deterministic term (i.e., $G_{t}=G+g>0$ ), and with probability $1-p$, it is below it (i.e., $G_{t}=G-g$ ). Note that, in the symmetric case in which $p=0.5$, we have $E\left(G_{t}\right)=G$. We restrict $G_{t} \geq 0$, entailing that $g \leq G$. Second, ideology is formed when agents are young and transmitted to them from their parents. In subsection 2.2.2 below, we define what ideologies entail and discuss the various mechanisms through which they may intergenerationally

${ }^{10}$ There is no population growth in the model because our empirical applications are not affected by population growth. Interesting dynamics with respect to population growth could arise, but they do not alter the fundamental insights of the model.

${ }^{11}$ This formulation is consistent with a ruler who also lives two periods, but whose dynasty is in political control over the infinite time horizon.

${ }^{12}$ As in some other conventional political economy models, we could consider alternative specifications in which the Ruler acts in the interest of a sociopolitical or economic class. These could then generate potential mechanisms through which institutions would not be upgraded even when it is economically efficient to do so. Thus, in order to isolate and identify the impact of ideological dynamics on institutional evolution, we choose this specification in which the socially efficient courses of action are aligned with the Ruler's interests. 
be transmitted. Third, $I_{t}$ denotes the efficacy of institutions in period $t$, which is affected by the extent of institutional investment adopted by the Ruler in a manner we shall discuss below.

Taken together, the effective total factor productivity of the economy, $A_{t}$, is determined by the combination of technology, ideology and institutional efficacy according to a constant elasticity of substitution production function with elasticity of substitution parameter $\theta \in(-\infty, 1)$ and share parameters $\{\alpha, \beta\} \in[0,1]$, where $\alpha+\beta<1$. In particular, we have

$$
A_{t}=\left[\alpha\left(G_{t}\right)^{\theta}+\beta\left(D_{t}^{o}\right)^{\theta}+(1-\alpha-\beta)\left(I_{t}\right)^{\theta}\right]^{\frac{1}{\theta}}
$$

In what follows, we determine the intertemporal steady state of our economy. We then consider the dynamic evolution of the economy in response to the two types of technology shocks: permanent productivity improvements as exemplified by higher $G$, such that $\widehat{G}=G+\Delta G$ for some $\Delta G>0$, and transitory shocks that increase volatility and are represented by higher $g$ such that $\widehat{g}=g+\Delta g$, for some $\Delta g>0$. Since $G_{t} \geq 0$, we restrict $\Delta g$ such that $\Delta g \leq \widehat{G}-g$.

\subsection{Ideologies and Mechanisms of Intergenerational Transmission}

\subsubsection{Definitions \& Functions}

A salient feature of ideology is that it helps individuals make generalizations about the complex environment within which they operate and about which they have incomplete knowledge. Accordingly, ideologies not only influence how individuals interpret their experiences, but also complement the factual information they possess. Implicit in these assertions is the notion that ideologies may be economically useful. Indeed, the roots of the idea that ideologies help to serve an economic purpose can be traced to Adam Smith, who recognized one form of ideology, religion, as a rational means for individuals to enhance their human capital (North 1981, p. 49; Iyigun, Mocan, and Owen 2001; Greif and Mokyr 2016).

Naturally, the purpose of ideologies can be interpreted in different ways. For instance, one can subscribe to the view that ideologies are non-deductive sets of beliefs about "right" and "wrong," and that they serve a more normative approach to life rather than provide a general framework with which to make judgements about how things work. In presenting the model below, we adopt the notion that such a framework forms the basis of making normative judgements. Put another way, we argue that, while ideologies may help individuals form beliefs about what is "right" and what is "wrong," they do so within the context of some working hypotheses about their economic environment. ${ }^{13}$

North (1981, p. 47) best summarizes the functional role of ideologies that we employ below: "Ideology is an economizing device by which individuals come to terms with their environment and are provided with a 'world view' so that the decision making process is simplified. [It] is inextricably linked with moral and ethical judgments about the fairness of the world the individual perceives. This situation clearly implies a notion of possible alternatives. Individuals alter their ideological perspectives when their experiences are inconsistent with their ideology. In effect, they attempt to develop a new set of rationalizations that are a better 'fit' with their experiences."

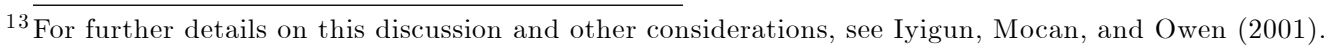




\subsubsection{Intergenerational Ideological Transmission \& Education}

In terms of the intergenerational transmission of ideologies (or, interchangeably, doctrines hereafter), there are equally compelling, empirically plausible and historically relevant alternatives. In this section, we shall articulate and develop two alternative mechanisms.

According to the first one, parents can indoctrinate their children with their own ideology for free (i.e., by simply being around their offspring and mainly through cultural spillovers). Or they can invest in some form of education (i.e., experience outside the house), $e \in[0,1]$, which equips the offspring with the cognitive skills necessary to assess the technological and productive environment more objectively. In particular, we shall assume that "formal" and private education equips the offspring to more accurately comprehend the next period's expected level of technology, $E\left[G_{t+1}\right] .{ }^{14}$ Hence, according to this formulation, we write $D_{t}^{y}$ $=e E\left[G_{t+1}\right]+(1-e) D_{t}^{o}$, where $D_{t}^{y}$ represents the ideological beliefs or knowledge that a young person is indoctrinated with by her parents while she is young. We assume neither depreciation nor further investments in this stock variable when the agent is old, hence it follows that $D_{t+1}^{o}=D_{t}^{y}$.

Under this formulation, the channel of indoctrination and ideological transmission is the parent/offspring relationship. And the education system, which entails private costs, provides the channel through which future workers can acquire skills that enable them to more objectively comprehend the production environment in which they will be economically active. Education may provide technical or academic skills, depending on the state of technology and the degree to which technological changes are skill biased (Goldin and Katz 1998, 2008). Importantly, however, we are not modeling education as translating into the skills or human capital required to use the technology. Instead, our focus is on the transformative effects of education on one's world view through which one comes to terms with their environment.

In our second formulation, the channel of ideological transmission is (free) public education, whereby the public education system is used to propagate a political regime's potentially self-serving and preserving ideology and political doctrines. For instance, Cantoni et al. (2017) show that between 2004 and 2010, Chinese education successfully aimed, via textbooks, to shape attitudes favoring China's governance and views on democracy and free markets. ${ }^{15}$ In this formulation, parents can send their children to school for free, $e \in[0,1]$, and time spent at school helps to propagate the existing state ideologies and political doctrines. Thus, in order to escape such indoctrination, parents need to invest in a form of private education, $1-e \in[0,1]$, which equips their offspring with the cognitive skills necessary to assess the technological and productive environment more objectively. On this basis, we write $D_{t}^{y}=(1-e) E\left[G_{t+1}\right]+e D_{t}^{o}$.

In both formulations, parents must invest resources in order to increase the preparedness of their children for future states of the world. In what follows, we shall solve our model according to the first formulation, although the qualitative nature of our key contentions would be operative under both mechanisms. Nevertheless, the role of education in the dynamics would be vastly different. Later, in Section 4, we revisit this issue and contrast some of the model's implications under the two mechanisms.

\footnotetext{
${ }^{14}$ This is a similar formulation to Bisin and Verdier (2001), where parents invest in their children's beliefs as a form of parental altruism.

${ }^{15}$ Similarly, Lott $(1990,1999)$ argues that public schools in the West indoctrinate students in order to instill values favorable to wealth transfers.
} 


\subsection{The Equilibrium}

\subsubsection{The Ruler's Problem}

After observing the realization of $G_{t}$, the Ruler chooses institutions, $I_{t}$, to maximize lifetime tax revenue discounted at rate $\delta \in(0,1)$, minus the cost of maintaining institutions, $c(\cdot) .{ }^{16}$ The cost of maintaining institutions is strictly increasing and convex in expenditures so that $c(0)=0, c^{\prime}>0$, and $c^{\prime \prime}>0$. We assume there is some exogenously set tax rate, $\tau \in[0,1]$, which determines the portion of output the ruler receives. ${ }^{17}$ The period $t$ strategy set of the Ruler can therefore be written as $s_{t}^{R}=I_{t} \in \mathbb{R}^{+}$. The Ruler's utility is written:

$$
U_{t}^{R}=\sum_{j=t}^{\infty} \delta^{j-t} E\left[\tau y_{j}-c\left(I_{j}\right) \mid s_{j}^{o}, s_{j}^{R}\right] .
$$

In every period, the Ruler maximizes (2) by choosing, $\forall j \in[t, \infty], I_{j}$, subject to $y_{j}=A_{j} \ell_{j}$ and $A_{j}$ given by (1).

\subsubsection{The Citizens' Problem}

Simultaneous with the institutional choice of the Ruler, old agents choose levels of education $\left(e_{t}\right)$ and consumption $\left(c_{t}\right)$ to maximize their utility from their own consumption and the consumption possibilities of their children, subject to $e_{t}+c_{t} \leq(1-\tau) y_{t} .{ }^{18}$ Their choices are conditional on the ideology they formed when young (i.e., $D_{t}^{o}=D_{t-1}^{y}$ ), the prevailing institutions $\left(I_{t}\right)$, and the tax rate $(\tau)$. The period $t$ strategy set of the old agent is therefore denoted $s_{t}^{o}=\left(e_{t}, c_{t}\right) \in[0,1] \times \mathbb{R}^{+}$. Old agents are altruistic, placing weight $\lambda \in \mathbb{R}^{+}$on the consumption possibilities of their children (i.e., $\left.(1-\tau) A_{t+1}\right)$. Assuming log utility, the utility of the old agent is written:

$$
U_{t}^{o}=\log \left(c_{t}\right)+\lambda \log \left[(1-\tau) E\left(A_{t+1}\right)\right]
$$

The citizen maximizes (3) by choosing $e_{t}$ and $c_{t}$ subject to $e_{t}+c_{t} \leq(1-\tau) y_{t}$.

Note that, when parents' beliefs can most objectively assess the current production environment, $D_{t}^{o}=$ $E\left[G_{t+1}\right]$. Consequently, $\forall e \in[0,1], D_{t}^{y}=D_{t}^{o}$ and parents will have no incentive to invest in education which is costly. Hence, in more predictable and stable environments where it is more likely that $D_{t}^{o}=E\left[G_{t+1}\right]$, traditional values would be passed on from one generation to the next. ${ }^{19}$

\subsubsection{Response Functions and the Intra-Temporal Equilibrium}

The intra-temporal equilibrium of such an economy is one in which each agent takes the optimal choices of the other as given and decides on her optimal allocations. This involves an intra-temporal equilibrium based on the reaction functions of the Ruler and the old agent.

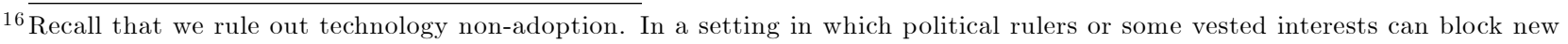
technologies, stagnation in technologies, institutions, and ideologies trivially and naturally occur. Instead, our main focus is one in which technological change is the main driver of the evolution and interplay between socially prevalent ideological beliefs and political institutions.

${ }^{17}$ The assumption that the tax rate is exogenous is not far-fetched if the model is applied to the pre-modern setting, where rulers had weak fiscal capacity and generally extracted the maximum amount possible subject to the constraint of weak fiscal institutions. Nevertheless, one can extend our model to endogenize the tax rates although doing so would not have a qualitative material impact on our key contentions.

${ }^{18}$ Formally, the old agent chooses a level of labor, $\ell_{t}$, to supply as well. Since we ignore utility from leisure, there is no choice but to provide labor with one's time. Thus, we drop this formality and embed the optimal labor choice into the decision problem, as a result of which we have $\ell_{t}=1$.

${ }^{19}$ This is in line with the empirical findings of Giuliano and Nunn (2016) who show that societies tend to emphasize traditional values more in relatively stable and predictable environments.
} 
Accordingly, the reaction function of the Ruler is implicitly defined by the first-order condition of the optimization problem we described above:

$$
\frac{\tau \delta}{1-\delta} \frac{\partial E\left(A_{t}\right)}{\partial I_{t}}-c^{\prime}\left(I_{t}\right) \leqslant 0
$$

where

$$
\begin{aligned}
\frac{\partial E\left(A_{t}\right)}{\partial I_{t}}= & p(1-\alpha-\beta)\left(I_{t-1}\right)^{\theta-1}\left[\alpha(G+g)^{\theta}+\beta\left(D_{t}^{o}\right)^{\theta}+(1-\alpha-\beta)\left(I_{t-1}\right)^{\theta}\right]^{\frac{1}{\theta}-1} \\
& +(1-p)(1-\alpha-\beta)\left(I_{t-1}\right)^{\theta-1}\left[\alpha(G-g)^{\theta}+\beta\left(D_{t}^{o}\right)^{\theta}+(1-\alpha-\beta)\left(I_{t-1}\right)^{\theta}\right]^{\frac{1}{\theta}-1}
\end{aligned}
$$

And that of the old agent is implicitly based on the first-order condition of her maximization problem:

$$
\begin{gathered}
-\frac{1}{(1-\tau) A_{t}-e_{t}}+\frac{p \beta \lambda\left(E\left[G_{t}\right]-D_{t}^{o}\right)\left[e E\left[G_{t}\right]+(1-e) D_{t}^{o}\right]^{\theta-1}}{\alpha(G+g)^{\theta}+\beta\left(e E\left[G_{t}\right]+(1-e) D_{t}^{o}\right)^{\theta}+(1-\alpha-\beta)\left(I_{t}\right)^{\theta}} \\
+\frac{(1-p) \beta \lambda\left(E\left[G_{t}\right]-D_{t}^{o}\right)\left[e E\left[G_{t}\right]+(1-e) D_{t}^{o}\right]^{\theta-1}}{\alpha(G-g)^{\theta}+\beta\left(e E\left[G_{t}\right]+(1-e) D_{t}^{o}\right)^{\theta}+(1-\alpha-\beta)\left(I_{t}\right)^{\theta}} \leqslant 0 .
\end{gathered}
$$

Taking equations (4) and (6) at strict equality, equations (4), (5), and (6) implicitly define two reaction functions, $I_{t}\left(e_{t}\right)$ and $e_{t}\left(I_{t}\right)$, that characterize the intra-temporal equilibrium of this economy, with $\bar{I}_{t}\left(\bar{e}_{t}\right)$ and $\bar{e}_{t}\left(\bar{I}_{t}\right)$ denoting an equilibrium. Given that it is impossible to derive closed form solutions for this twoequation system, we shall, in Section 2.4 below, turn to numerical simulations to demonstrate the existence of equilibrium outcomes and derive comparative statics.

\subsection{Numerical Simulations}

In what follows, we parameterize our model and show the existence of an intra-temporal equilibrium. Then, we illustrate the steady state to which our economy would converge, given a choice of parameter values. We begin by considering shocks that occur when a society is in a steady state. Focusing on steady states permits us to transparently address the questions raised in the introduction. When will a society fail to adopt more efficient institutions in response to changing economic conditions? And why do ideologies sometimes fail to update under such conditions?

The steady state of the economy described above is defined by $\Delta I_{t}=0, \bar{e}=0, I_{t}=\bar{I}$, and $D_{t}^{y}=D_{t}^{o}=\bar{D}$, $\forall t \geqslant T \geqslant 0$. Denote the pre-shock steady state ideologies and institutions as $\bar{D}_{0}$ and $\bar{I}_{0}$ and denote the post-shock steady state ideologies and institutions as $\bar{D}_{1}$ and $\bar{I}_{1}$. The steady state presents a baseline case in which we show the conditions under which ideologies and institutions do and do not respond to TFPenhancing technological shocks. The absence of ideological updating is interpreted as a society maintaining the pre-shock ideology that "worked" for it in the past.

We proceed to consider shocks that occur while the economy is on the path to the steady state. Such a scenario may result in a conservative revival, as we defined in the introduction. Under some sets of parameters, a TFP-enhancing - yet risky - technology shock discourages ideological updating in spite of the fact that such updating would have occurred in the absence of the shock. Hence, society views the world 
through a more traditional lens than it would have in the absence of the shock, even though the shock is, on average, productivity enhancing.

\subsubsection{Shocks in the Steady State}

In order to operationalize our model, we assume that the cost of institutional maintenance takes the explicit form: $c^{\gamma}, \gamma>1$. With that, the top panel of Table 1 presents the eight parameter choices one needs to make in order to numerically solve this model. We work with a two percent time discount factor throughout $(\delta=0.98)$, assume some moderate degree of complementarity among the three determinants of total factor productivity $(\theta=-6)$, a constant income tax rate of ten percent $(\tau=0.10)$, and a moderately high level of benevolence toward offspring $(\lambda=2)$. In the next panel of Table 1, we set the initial level of our two preshock technology variables, $G$ and $g \cdot{ }^{20}$ In Case I, the mean pre-shock level is high relative to the variance, while in the remainder of the cases the pre-shock variance is greater. The bottom panel in Table 1 shows the pre-shock steady state levels of $D_{0}^{o}$ and $I_{0}$. These are determined by the level of $D_{0}^{o}$ in which the optimal level of $e$ is equal to $0 .{ }^{21}$

Table 1: Numerical Simulations

\begin{tabular}{ccccc} 
Parameters & Case I & Case II & Case III & Case IV \\
\hline \hline$\alpha$ & 0.3 & 0.3 & 0.3 & 0.3 \\
$\beta$ & 0.3 & 0.3 & 0.3 & 0.3 \\
$\theta$ & -6 & -6 & -6 & -6 \\
$\delta$ & 0.98 & 0.98 & 0.98 & 0.98 \\
$\tau$ & 0.1 & 0.1 & 0.1 & 0.1 \\
$\gamma$ & 1.2 & 1.2 & 1.2 & 1.2 \\
$\lambda$ & 2 & 2 & 2 & 2 \\
$p$ & 0.5 & 0.5 & 0.6 & 0.4 \\
\hline \hline \multicolumn{5}{c}{ Pre-Shock Technology } \\
$G$ & 10 & 10 & 10 & 10 \\
$g$ & 1 & 5 & 5 & 5 \\
\hline \hline & Pre-Shock Steady State \\
$\bar{D}_{0}$ & 6.04 & 5.22 & 5.69 & 4.81 \\
$\bar{I}_{0}$ & 6.88 & 5.68 & 6.16 & 5.30
\end{tabular}

In Cases I and II, we compare two scenarios that only differ in the magnitude of their pre-shock technology risk, with Case II exhibiting much higher variance. In Cases III and IV, we vary the probability that TFP shocks are positive (denoted by the parameter $p$ ). For each of these cases, we investigate the post-shock, steady-state equilibrium outcomes that arise when we vary the size of the shock, $\Delta G$, and the associated change in variance due to the shock, $\Delta g$.

In Case I, the level of technology, $G$, is much greater than its variance, $g$. Under such a scenario, a large shock to the level of technology, $\Delta G$, will entail a corresponding update to ideology and institutions unless coupled with a very large shock in variance, $\Delta g$. As seen in Figure 1, there are three possible post-shock outcomes (note that the upper region is "not possible" because the variance shock cannot be so large that a negative technology shock, $-g$, would entail negative productivity, or $\Delta g \leq \widehat{G}-g$ ). When

${ }^{20} \overline{\text { We run numerous sensitivity checks to ensure that }}$ our results are not simply reflections of the parameters chosen. The results of these checks are reported in Appendix Table A1 and Figure A4.

${ }^{21}$ At any level of $D_{0}^{o}$ beneath the ones we list in the table, the optimal $e$ would also equal 0 , since the old agent would choose a corner solution. We choose to start at the highest level of $D_{0}^{o}$ for which a steady state exists. 
the technology shock $(\Delta G)$ is large and the variance shock $(\Delta g)$ is small, the steady-state ideologies and institutions positively update in response to shocks. This results because of the complementarities between technology, ideology, and institutions. As the technology gets better-but not commensurately riskier - the benefit to old agents of investing in the education of their offspring is great enough that it outweighs the cost of foregone consumption (i.e., $e>0$ in the period after the shock). Likewise, the benefit to the ruler of improving institutions - which increases due to better technology and ideologies commensurate with the improved technology — outweighs the increased cost associated with maintaining those institutions, $c(\cdot)$.

Figure 1: Case I; $G=10, g=1$

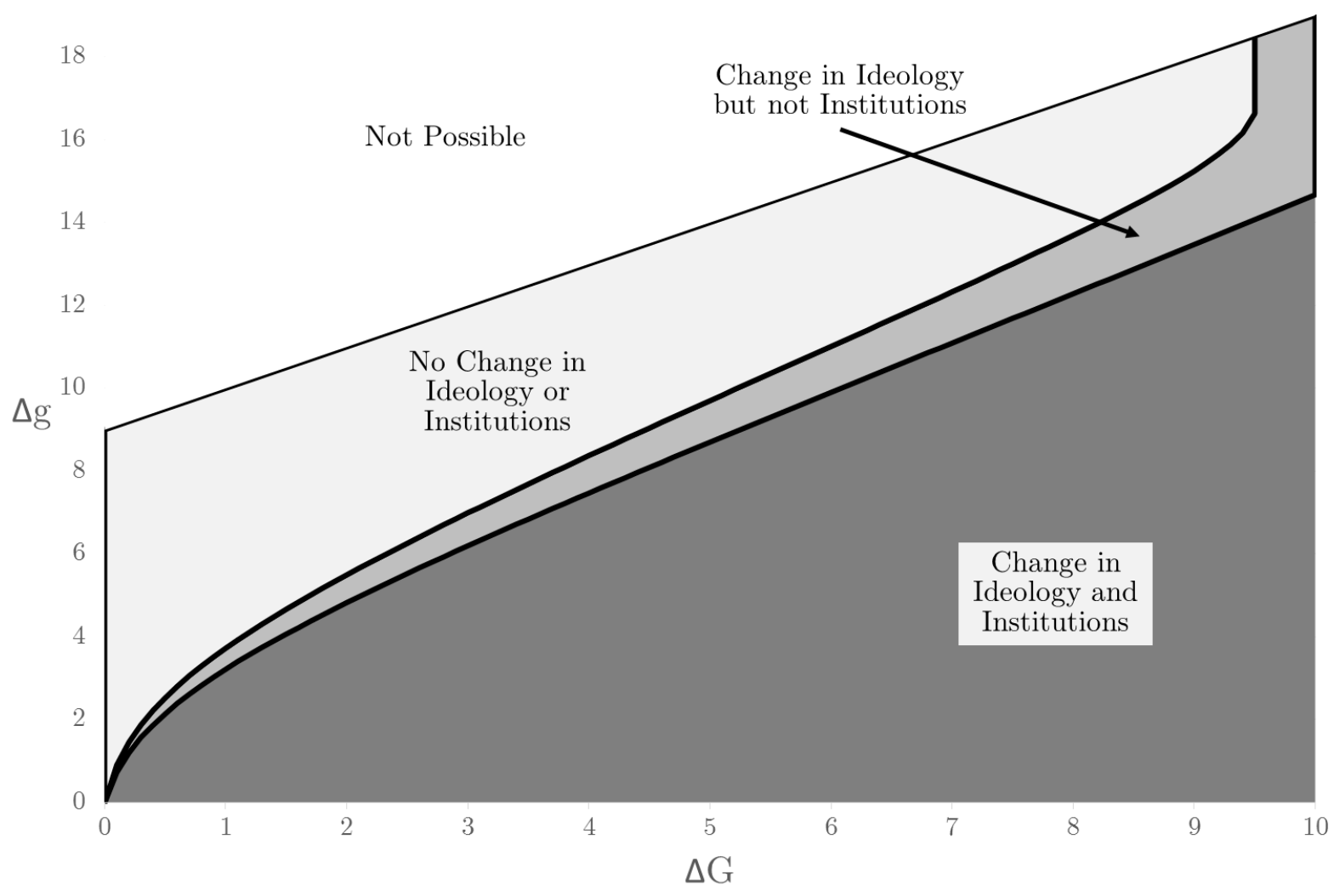

When a more modest technology shock $(\Delta G)$ is coupled with a relatively large variance shock $(\Delta g)$, neither ideologies nor institutions change in response to the shock. Despite improved-yet riskier - technology, the society's ideology and institutions remain what they were prior to the shock. In other words, the society holds onto what worked for it in the past in the face of a changing world.

Our model explains why this outcome can arise. In the face of a risky new technology, risk-averse old agents are less inclined, on the margin, to invest in the education of their children, since their children's expected utility from such an investment is decreasing in $\Delta g$. Likewise, the convexity of the ruler's institutional cost curve, $c(\cdot)$, entails that expected costs from improved institutions are increasing in $\Delta g$. The key insight is that these two phenomena interact: inferior ideologies of the old discourage investment in institutions by the ruler, which discourages investment in ideology by the old, and so on. In short, the negative interaction 
between ideology and institutions entails that neither update after the shock. ${ }^{22}$

In our next three numerical exercises, Cases II-IV (Columns 2-4 of Table 1), we explore the impact of a higher initial variance in technology, $g$. The exercise in Column 2 holds all other parameters constant, while the exercises in Columns 3 and 4 vary $p$, the probability that the shock is positive. The general shape of each of these figures looks the same as in Figure 1, so we will not elaborate on the intuition underlying them, and we graphically report the equilibrium spaces for each cases in the Appendix (Figures A1, A2, and A3).

We summarize the differences between the four cases in Figure 2, which shows their "ideological transition frontiers". This frontier is defined as the line which separates the zones between which ideology responds to the shock and that which it does not respond. In Figure 2, any shock parameters above the frontier indicate that there is no change in pre-shock and post-shock ideology. Figure 2 reveals that, given a small (less than 6) increase in the level of technology, $\Delta G$, ideology fails to update for smaller incremental increases in $\Delta g$ in Cases II-IV, when the initial variance in technology, $g$, is already large, relative to Case I. Put differently, the ideological transition frontier has a significantly smaller slope in Cases II-IV than it does in Case I. Consequently, it takes a smaller uptick in the riskiness of any technological improvement for new technologies to fail to induce a corresponding change in ideology.

Figure 2: The Ideological Transition Frontier, Cases I-IV

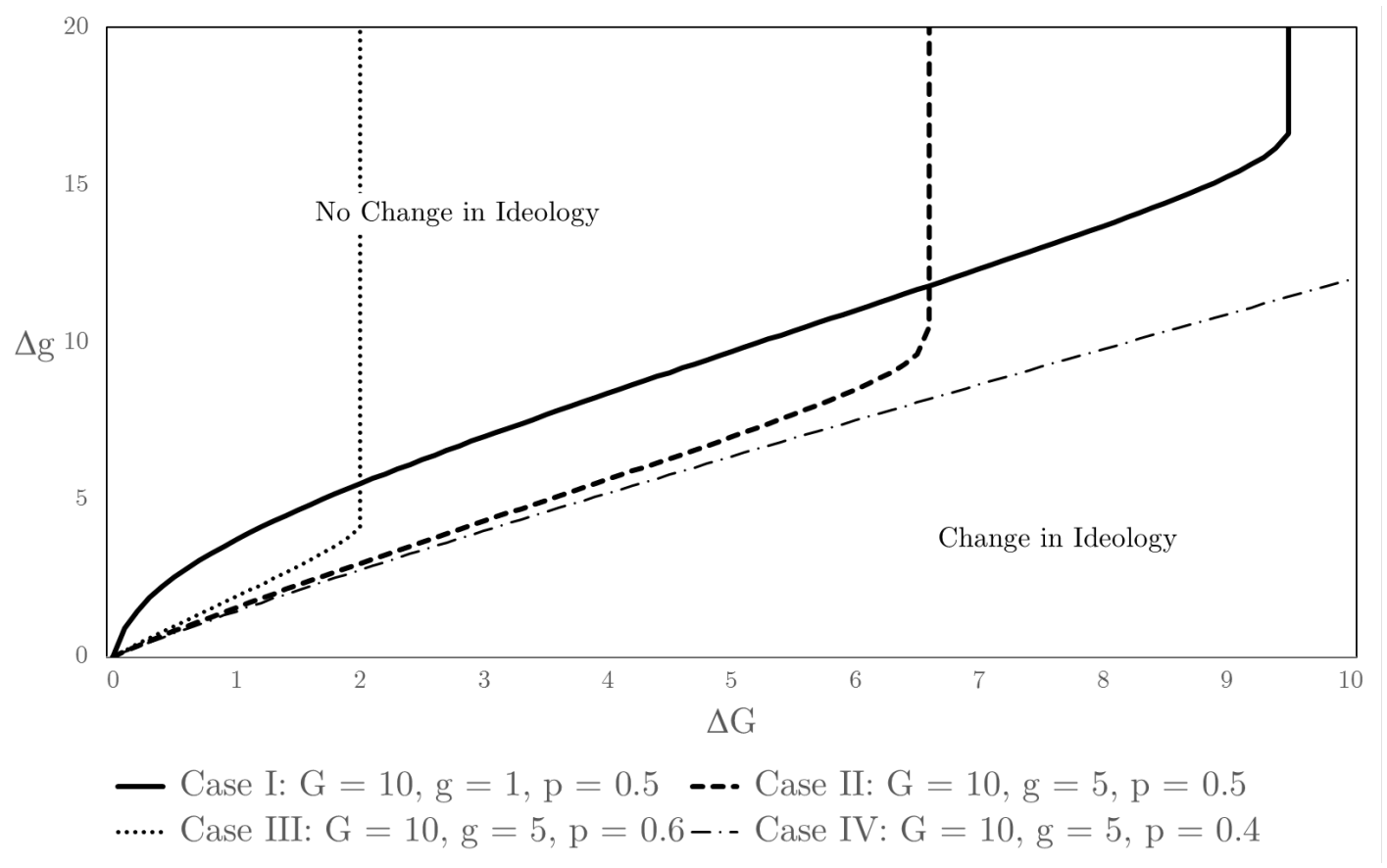

In Case III, the probability of a positive shock is increased to $p=0.60$, but all other parameters are the same as in Case II. It is clear that in Case III a post-shock change in ideology occurs over a large part of

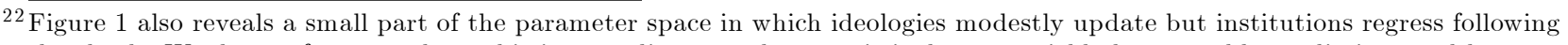
the shock. We do not focus much on this intermediate case because it is does not yield clear testable predictions and because the space over which it is an equilibrium is small. Yet, it is useful to provide some intuition for the existence of this space. Under certain sets of parameters, when shocks are of a magnitude such that ideologies update modestly following a shock, the increase in both the level of technology and the modest increase in ideology do not provide enough incentive for the ruler to upgrade institutional capacity relative to the increase in marginal cost associated with riskier technology. In such a situation, the ruler prefers to let institutions decay in order to diminish his exposure to risk. 
the parameter space. The intuition is straight-forward: the higher that $p$ is, the greater the expected value of technology in the future. Since technology is complementary to ideology and institutions, there is more incentive for old agents to invest in education, $e$, when $p$ is large. This logic also explains the equilibrium outcomes in Case IV, in which $p=0.40$. Since $p$ is smaller than in any of the other cases, it follows that the space over which ideology updates in response to the technology shock is smaller.

\subsubsection{Shocks in (Steady-State) Transition}

Finally, we consider what happens when the shock occurs when the economy is out of the steady state (and in the transition to it). This could happen, for instance, in a society where technology is changing rapidly or one in which exogenous events (e.g., war, natural disaster) affect culture or institutions. It is precisely such a shock that may result in a conservative revival. That is, ideology may fail to update despite the fact that it would have without the shock and despite the fact that the shock is TFP-enhancing. This is what we mean by conservative revival: society views the world through a more traditional lens than it would have in the absence of the shock, despite the shock being, on average, productivity enhancing.

To this end, we study a representative case in which all parameters are the same as in Case I, except that the initial ideology is set to $\bar{D}_{0}=5$ (rather than $\bar{D}_{0}=6.04$, which entails a steady state). Under such conditions, $I=7.015$ and $e=0.234$ in the first period of transition and the economy will ultimately converge to a new steady state with a higher level of ideology, in the absence of a shock.

We show how ideology and institutions are affected under varying types of shocks which occur before the old agent chooses $e$. The outcomes are reported in Figure 3. We first show what happens in the absence of a shock. On the transition to the steady state, $e$ is positive $(e=0.23)$ and remains so until the returns to education have diminished to the point where old agents' optimal choice of $e$ is 0 . This entails a larger level of ideology once the steady state is reached; in this case, the steady-state ideology is 6.17 .

We continue by considering three types of shocks, all of the same magnitude, $\Delta G=5$ : a "low variance" shock in which $\Delta g=1$, a "high variance" shock in which $\Delta g=8$, and a "very high variance" shock in which $\Delta g=12$. Note that in each of these three cases, the expected technology level, $E\left(G_{t+1}\right)$, increases from 10 to 15. When a low variance shock hits an economy on the transition to the steady state, the benefits of higher TFP outweigh the corresponding increase in variance, and old agents choose higher levels of $e$ than they would have in the absence of the shock (0.46 vs. 0.23 ). This results in higher levels of ideology, more suited to the improved technological environment, for future generations. It also triggers a positive institutional response from the ruler for two reasons. First, the better technology is complementary to better institutions, encouraging the ruler to improve institutions. Second, the ruler anticipates ideologies that are more in sync with the technologies in the future and thus chooses more effective institutions than he would in a one-shot game.

When a "high variance" shock $(\Delta g=8)$ hits the economy, the change in ideology and institutions is more subdued. The technology variance is not so large as to discourage old agents from investing in education altogether ( $e=0.22$ in the following period), and thus ideology increases more than it would have in the absence of a shock, but not nearly as much as it does in the presence of the low variance shock. Correspondingly, institutions improve, but are only slightly better than they would have been in the absence of a shock.

Finally, we consider the case when a "very high variance" shock $(\Delta g=12)$ hits the economy on the path to the steady state. As Figure 3 makes clear, ideological progression halts in the presence of such a shock (i.e., $\bar{D}_{0}=\bar{D}_{1}=5$ ), old agents do not invest in education $(e=0)$, and institutions become worse (changing 
Figure 3: Ideology and Institutions Following a Shock during the Steady-State Transition

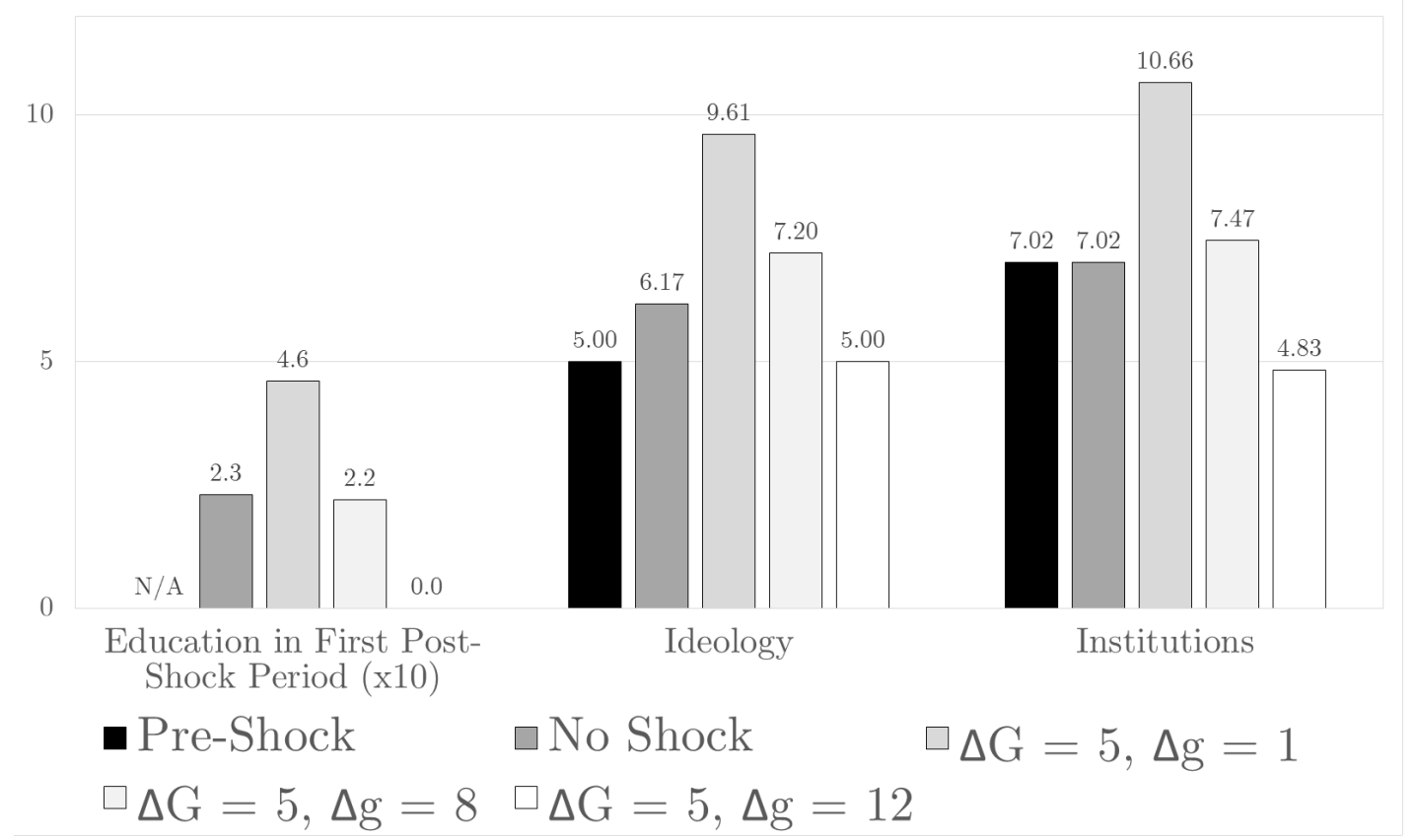

Notes: All parameters are the same as in Case I, except that initial beliefs are set to 5, not 6.04. "Pre-shock" refers to the level of ideology and institutions prior to the shock. "No Shock" refers to what ideology and institutions would have converged to in the steady state had no shock occurred. The right-most three bars show the eventual steady-state ideology and institutions given shocks of various magnitudes.

from 7.02 to 4.83). This is what we have in mind by a conservative revival. Despite the fact that ideology would have improved from 5.00 to 6.17 in the absence of a productivity-enhancing shock, ideology remains at 5.00 after the shock. In other words, high enough variance risk encourages people to stick with the ideology that worked for them at one point in the past rather than updating as they would have in the absence of the shock. Meanwhile, institutions degenerate following the shock for two related reasons. First, the cost of maintaining institutions is convex, and thus the expected cost-benefit ratio is increasing in the variance of the technology. The second reason has to do with complementarities between ideology and institutions. Prior to the shock, the ruler chose a level of institutions that took into account the future increase in ideology - and therefore the better production environment. If $\Delta g$ is large enough that old agents reduce their investment in education to 0 , the ruler will scale back investment due to there being no future positive feedback between institutions and education.

In sum, the model reveals the conditions under which TFP-enhancing shocks result in corresponding improvements in ideology and institutions which make both more capable of adopting and employing improved technologies. When the shocks are associated with a small change in technological variance, ideology and institutions accommodate the new technology, since the benefits of doing so outweigh the costs. However, when the shocks also carry with them much higher technological variance, society's ideologies and institutions may fail to update (or even regress), even if ideologies and institutions were in the process of updating in the absence of the shock. The latter case is more likely to arise when the new technology is truly foreign, as was the case in the early modern and industrial period when new Western technologies and institutions were introduced to much of the rest of the world. We turn to these cases in the following section, providing 
analytic narratives in support of the model's key insights.

\section{Historical Evidence}

In this section, we support the insights of the model with five analytical narratives from three countries. Each of these narratives highlights the ideological and institutional reaction of non-Western societies when first confronted with Western institutions and technologies. This is precisely the condition under which the model predicts a "conservative revival" may arise: despite post-industrial technologies being much superior in terms of productivity, they also carried immense uncertainty regarding how they would "fit" the existing institutional and ideological bases upon which the non-Western societies were built. The five narratives cover the long-run history of the Ottoman Empire's evolving political and institutional response to modernize and cope with a rapidly industrializing Europe, the inward turn of Qing China during the Tongzhi Restoration, and the rapid industrialization and modernization of the Japanese economy during the Meiji era, following conservative reform episodes during the Tokugawa Shogunate.

\subsection{The Ottoman Empire}

It was by no means obvious in the 16th century that the Ottoman Empire would eventually fall behind its Western European rivals. Territorially, the Empire expanded throughout the century and eventually ruled most of the North African coast, the Arabian Peninsula, the Balkan Peninsula, and most of the Middle East. Indeed, the Ottomans repeatedly threatened the great powers of central and southern Europe-Spain, Venice, and the Holy Roman Empire.

Yet, by the end of the 17th century, the Ottomans had clearly fallen behind. Even prior to the Industrial Revolution, this reversal of fortune was especially apparent with respect to technology (Mokyr 1990). Our model is well suited to explain the Ottoman reaction to European economic and technological advancements. The Ottomans were hardly unaware that the tables began to turn in the seventeenth century; they were in close contact with the West when profound economic changes were beginning to take shape in Europe. As early as the first part of the seventeenth century, the Ottomans seem to have caught on rather quickly that the world was rapidly changing. The prototype reformist sultan was Osman II, whose reign lasted from 1618 to 1622. He was followed by Sultan Murad IV (r. 1623-40) and the exceptional era of Grand Vizier Mehmed Köprülü (r. 1656-83), who both followed up with reforms of their own.

In our model, technological changes, $\Delta G$, result in improved institutions to accommodate such changes if and only if the uncertainty associated with such technology, $\Delta g$, is not too large. When uncertainty is large, ideological beliefs regarding the appropriateness of the technology to the society's resource base will not update, and there will be little incentive for the ruling elite to update institutions. The latter insight provides an explanation for the Ottomans reaction to Western advancements and, in particular, why the early reformist sultans advocated conservative reforms. These Ottoman rulers clearly recognized that change was occurring in the West, but their operating premise was the inferiority of anything Western, and their instincts typically involved a stronger emphasis on the Muslim-Ottoman fundamentals. Shaw (1976, p. 175) labels this initial wave of reforms as the traditionalistic reform period:

It is erroneous to believe that the ruling class faced the internal decline without making any efforts to remedy the situation. There were reformers and reforms at crucial times during the seventeenth and eighteenth centuries. But even the most intelligent and perceptive of Ottoman 
reformers at this time adhered to the basic premise that the Ottoman system was far superior to anything that the infidel might develop, an attitude that had considerable justification only when it first evolved in the sixteenth century. According to this idea, the reason for Ottoman decline was a failure to apply the techniques and forms of organization that had achieved success at the peak of Ottoman power, normally equated with the reign of Süleyman the Magnificent. To the traditionalistic reformers of the seventeenth and eighteenth centuries, then, reform could be achieved by making the system work as it had previously.

An entire class of Ottoman political observers writing in the sixteenth through eighteenth centuries commented on the "decline" of the empire. One of the first of these writers was Mustafa Ali (1541-1600), who wrote a history of the empire during a time of Ottoman expansion-i.e., before it was obvious that the empire had fallen behind leading European powers. Ali's treatise is characteristic of what would become the "decline genre," which focused on deviations from the norms of Süleyman's reign (Howard 1988; Dale 2010). Ali's history laments the "rising corruption, disruption of the military, the declining power of viziers, the loss of authority of the madrasa-trained intellectual elite, ... economic problems, and the pernicious influence of the harem" (Dale 2010, p. 270). If the sultan and his administrators could just return to the pious and honest rule of Süleyman and his predecessors, Ottoman decline would be arrested.

Along these same lines, Lewis (2002, p. 45) notes how traditional Ottoman reforms emphasized a return to cultural and ideological roots: "The final answers given by traditional writers to the older formulation of the question [why did the West leap ahead?] were always 'let us go back to our roots, to the good old ways, to the true faith, to the word of the God.' With that of course there was always the assumption that if things are going badly, we were being punished by God for having abandoned the true path."

The most important and skilled writer on Ottoman stagnation was Koçi Beg, an intimate advisor of Sultan Murad IV (r. 1623-40), who wrote a treatise for Murad in 1630 and a description of Ottoman institutions and terminology for Sultan Ibrahim in 1640 (Howard 1988, p. 64; Lewis 1973, p. 203-7). Throughout his writings - many of which were used extensively by later writers of the genre - the concept of a past "Golden Age" under Süleyman is a dominant theme (or, the "imagined perfection" of the era before Süleyman, as denoted by Colin Imber [2016]). It was under Süleyman that administrative practices reached their ideal, but this ideal was long past: "It is a long time since the high-chambered household of the lofty Sultanate (may it remain under the protection of eternal grace) was served by solicitous, well-intentioned, worthy ulema and by obedient, self-effacing, willing slaves. Today the state of affairs having changed, and evil, upheaval, sedition, and dissension having passed all bounds, I have sought occasion to observe the causes and reasons of these changes, and bring them to the Imperial and august ear" (quoted in Lewis 1973, p. 203). It was the laziness of the sultan, the debasement of the Grand Vizier, the bloating of the Janisseries, and the venality of the judges - all practices far removed from the glories of the "imagined perfection" of the past - that were at fault for Ottoman decline (Lewis 1973, p. 204-6). Koçi Beg's writings were characteristic of the entire genre, ${ }^{23}$ having an "essentially conservative or backward-looking perspective" (Dale 2010, p. 272). Yet these writings were also optimistic, noting that a return to the past - a "conservative revival" to use our terminology — was all that was needed to bring back lost glory: "The enemies of the faith, seeing the good order and stability ... will say, in helpless fear and envy: 'The House of Osman lay for sixty years

${ }^{23} \overline{\text { For instance, an anonymous treatise entitled Kitā }}$-i Müstetäb from about 1620 argues that the Ottomans were so successful from the founding of the dynasty until the reign of Murād III (1574-1595) because they followed Shari'a (Islamic law) and kanun (secular law) and had just administration. The author contrasts that situation with the present, where decline versus the West had already commenced (Howard 1988, p. 71). For many more examples, see Lewis (1973, ch. 15), Howard (1988), and Dale (2010, p. 270-287). 
in neglectful sleep, but now they are wide-awake, and have begun to make good the shortcomings of past days'" (quoted in Lewis 1973, p. 207).

Simply put, it was not obvious to the Ottomans of the time that European institutions were superior to Ottoman ones, particularly those put in place during the Ottoman rise to power. This was a period of rapid change in Europe, and while European institutions worked well in the European context, they clashed with the ideological belief of Ottoman superiority. Indeed, if it were just a matter of transplanting institutions independent of ideology, this would have been straight-forward enough. But ideological beliefs centered on the superiority of Ottoman institutions were slow to update. In the process, Ottoman institutions fell behind. This is a classic case of what we describe in the model as a "conservative revival." In the face of a vastly changing, yet uncertain, world, Ottoman beliefs in their own superiority failed to change and, as a consequence, Ottoman institutions failed to accommodate institutional and technological advances.

The failure of the tımar system provides an excellent example of the interaction between antiquated institutions and conservative ideological beliefs. At the height of Ottoman power in the fifteenth and early sixteenth centuries, the sultan derived two-thirds to three quarters of his revenue through the timar system, a military lease contract whereby the provincial cavalry collected agricultural taxes directly from the peasantry as remuneration for their military services to the state. The trmar system was similar to the tax collection system of feudal Europe, where local feudal lords controlled revenues in return for military service. But as Ottoman expansion ceased and the sultan was no longer able to provide new tımars to the military elite, the system began to fail and the central government received less tax revenue (İnalcık 1973, ch. 13; Hourani 1991, ch.13; Coşgel and Miceli 2005). To address this revenue shortfall, the state eventually (in 1695) sought larger short-term payouts in return for lifetime tax farms under an institution known as the malikane system. But this system failed, too, as tax farmers passed down their farms to their heirs instead of returning them to the state, and some tax farmers stopped sending in revenues altogether (Pamuk 2004; Balla and Johnson 2009).

The Ottoman failure to extract revenue stands in stark contrast to what the leading European economies were able to achieve. The sixteenth and seventeenth centuries were precisely the period when the leading European powers built large fiscal apparatuses and sovereign debt markets. They achieved this via institutions that constrained rulers and centralized tax collection (North and Weingast 1989; Dincecco 2009). As a result, a nation as small as the Dutch Republic was able to collect $42.5 \%$ more taxes than the Ottoman Empire by the 1650s despite having less than one tenth of its population. In per capita terms, the Dutch collected over 15 times the revenue of the Ottomans, and the Spanish, French, Venetians, and English all collected at least five times the per-capita revenue of the Ottomans (Karaman and Pamuk 2010, 2013).

How did Ottoman advisors and intellectuals respond to the decline of the trmar system? Instead of looking to Europe for solutions - and clearly certain European polities had found better institutional solutions to tax collection - Ottoman writers placed blame on corruption within the tımar system. If only the Ottomans could employ the system like it was used at the height of Ottoman power under Süleyman (and before), decline could be arrested. It was corruption and nepotism among tımar holders, not the tımar institution itself, that required amending (Howard 1988, pp. 59-73).

It was only after the Ottoman-Europe disparity became sufficiently large that the Ottomans accepted the superiority of European institutions and technology. Historians date the beginning of the Ottomans' decline to the Peace of Karlowitz signed between the Holy League and the Ottomans in 1699. With that treaty, the Ottomans ceded most of Hungary, Transylvania, and Slovenia to Austria; Podolia to Poland; and most of Dalmatia to Venice. According to Shaw (1976, p. 225), Karlowitz also marked the ushering in of 
the second-generation Ottoman reforms:

The loss of territories long considered integral parts of the empire also shook Ottoman morale to the point where, to many people, any kind of effort to save the empire seemed impossible. For the first time a few Ottomans began to see that reform was possible if only the empire could discover what Europe had done to achieve its new supremacy and incorporate what was best into the Ottoman system. Reformers now began to accept the possibility that Europe might have developed certain specific techniques that might be used to strengthen and preserve the traditional ways, particularly new forms of military organization and weapons. Traditionalistic reform, therefore, became a combination of old and new, creating an amalgam that, while not successful in itself, opened the way for a new style of modern reform during the nineteenth century.

Shaw's astute observation highlights two critical elements that speak volumes about how ideology came to bear on Ottoman economic calcification. First, only when the Ottoman Empire's inferiority became exposed with successive territorial losses against the Habsburgs was there a painful recognition that perhaps studying the ways of the Christian West - and not discounting them due to long-held beliefs regarding its culture and capabilities - was central to successful reforms. From the perspective of our model, this is akin to acknowledging that $\Delta G$ inherent in Western technologies and practices was actually larger than originally perceived (as opposed to assuming nothing significantly improved in terms of $G$ could originate in the West). As a clear indication of how difficult it must have been to shed those old assumptions and beliefs regarding the status of the West vis-á-vis dar-al-Islam, the reformer Sultans had to consult the ulemá (doctors of the Holy Law) for them to authorize two changes in the conduct of state affairs: "The first was to accept infidel teachers and give them Muslim pupils, an innovation of staggering magnitude in a civilization that for more than a millennium had been accustomed to despise the outer infidels and barbarians as having nothing of any value to contribute. The second was to accept infidel allies in their wars against other infidels." (Lewis 2002, pp. 21-22).

Second, there was an attempt to keep technology and ideology transfers confined to the military and national defense realms. Lewis (2002, p. 81) makes the case for this point about Islam vis-à-vis Christianity in general: "The relationship between Christendom and Islam in the sciences was now reversed. Those who had been disciples now became teachers; those who had been masters became pupils, often reluctant and resentful pupils. They were willing enough to accept the products of infidel science in warfare and medicine, where they could make the difference between victory and defeat, between life and death. But the underlying philosophy and the sociopolitical context of these scientific achievements proved more difficult to accept or even to recognize." The fact that military reforms took precedence over others helped subordinate the hurdles of cultural and religious beliefs, but it did not ensure the successful implementation of even the necessary reforms, as the empire was slow to adapt and it held the view that the fundamentals of its own military organization were superior to the West (Imber 2002, p. 284).

It was not until the 19th century unveiling of the Tanzimat Decree by Sultan Abdul Mecid (1839) that the Ottomans began to adopt Western institutions. The Tanzimat was the earliest constitutional document in any Islamic country and culminated with the establishment of the first ever House of Parliament in the Muslim world, the Meclisi Mebusan, in 1876 (Kinross, 1979, p. 474). It encompassed a series of reforms promulgated in the Ottoman Empire between 1839 and 1876 under the reigns of the sultans Abdülmecid I and Abdülaziz. These reforms were the epitome of what we label as "progressive" as they were heavily 
influenced by European ideas, with the intent to effectuate a fundamental change of the empire from the old system based on theocratic principles to that of a modern state.

Many of the key provisions of the Tanzimat reforms were set forth in the Hatt-ı Şerif of Gülhane (1839). This document called for the establishment of new institutions that would guarantee security of life, property, and honor to all subjects of the empire regardless of their religion or race. It also authorized the development of a standardized system of taxation to eliminate abuses and established fairer methods of military conscription and training. The promises of equality for non-Muslims (mainly Christians and Jews) living in the empire were not always carried out, but the balance of the changes provided for in the Noble Edict, along with other reform measures, were implemented principally under the leadership of Mustafa Reşid Paşa, who served six terms as grand vizier. The reforms included the development of a new secular school system, the reorganization of the army based on the Prussian conscript system, the creation of provincial representative assemblies, and the introduction of new codes of commercial and criminal law, which were largely modeled after those of France. These laws, moreover, were administered by newly established state courts independent of the ulemā, the Islamic religious council. ${ }^{24}$

But these reforms came too late. By the late 19th century, the Ottoman Empire was known as the "sick man of Europe", and its remnants were carved up by the victors of the First World War. What was a once powerful empire fell behind and could not catch up-not because it was incapable of adopting Western institutions, but because the beliefs of its people were incompatible with the adoption of Western techniques.

\subsection{The Road to Modern Japan}

Eighteenth and nineteenth century Japan, which witnessed the decline and fall of the Tokugawa Shogun followed by the Meiji Restoration, is another relevant case that highlights the key dynamics of our hypothesis. In particular, the last few decades of the Tokugawa era were exemplified by a number of reformist movements, almost all of which had a conservative spirit in the sense we defined above. By contrast, the Meiji Restoration was an initiative aimed at transforming Japanese society, economy, and institutions based on an acknowledgment of Western superiority.

The contrast between the Tokugawa era and the Meiji Restoration, as it relates to our hypothesis, is perhaps best expressed by Jensen (2000). In comparing the three waves of reform during the Tokugawa Shogunate and the initiatives during the Meiji Restoration, Jensen (2000, p. 237) notes:

Japanese historians distinguish three periods of shogunal rule as "reforms" and then refer to the Meiji "restoration" of 1868. In many respects, however, it would be more meaningful to refer to the "reforms" as attempted "restorations," since each of them tried to bring about a return to the remembered fiscal and administrative health and vigor of the seventeenth century. The Meiji changes, on the other hand, better deserve the term "revolution," for they brought permanent change to Japan's institutional life. Not one of the "reforms" succeeded in its goals, but each added institutional innovations in its attempts to deal with the increasingly complex problems of Japanese society.

The reform attempts during the Tokugawa Shogunate began in the early-18th century with those undertaken during the Kyōhō era. According to Jensen (2000, pp. 238-9), these were "practical reforms" undertaken in response to "changes that had come over Japan's political economy with the rise of commercialism." Likewise, the Kansei reforms, which took place nearly a century later at the turn of the 19th

24 www.britannica.com 
century, were seen as crude attempts to deal with the effects of urban commercialism. They included renovations in the educational system and the intellectual realm based on the orthodoxy of Chi Hsi Confucianism. Finally, the Tenpō reforms during the waning decades of the Tokugawa era were mostly ad hoc emergency responses to a series of natural disasters that widened Japanese sociopolitical rifts. These, too, aimed to reform education with a heavy emphasis on the traditional Confucian teachings and discipline (Jansen 2000, pp. 243, 248).

In analyzing the Samurai discontent and social criticism toward the demise of the Tokugawa Shogunate, Duus (1976, p. 53) discusses the arguments advanced by the contemporary Japanese thought leaders. He highlights that a common thread among them was a fundamentally conservative outlook that was based on Confucian principles: "Reformers criticized the present-day rulers of Japan not in the name of some new vision of society but in the name of received morality. They did not feel that older political standards were no longer valid, but rather that society did not live up to them. Hence most critics did not call for the overthrow of the bakuhan system or even of its constituted leaders. Instead they attacked the people in power for moral failing and urged them to return to ancient standards."

The Tokugawa reign, especially in the late-18th and early-19th centuries, was not short on practical reforms intended to cope with the effects of a higher degree of commercialism in Japanese society. But the latter were heavily influenced by attempts to restore the traditional Japanese morality, spirituality, and philosophies guided by conventional Confucian ideas. Moreover, the early interactions with the Western powers, even when they revealed direct or indirect evidence of the superiority of their technologies and institutional organizations, were met with some degree of existential denial. As Duus (1976, p. 57) states, "Any easy confidence that the Westerners might be put off by force was rudely shaken in the late 1830s by news of the Opium War in China. The defeat of the Chinese by a small British naval and military force was a tremendous shock. It shattered the image of Chinese centrality and strength. The sense of threat from without, smouldering since the 1790s and now fanned into more urgent fear by the Opium War, provoked debate among scholars, officials and concerned political leaders over how to best deal with the "barbarians." Their general stance was anti-foreign. Nearly all who participated in the debate agreed that the Westerners were either inferior or up to no good or both."

By stark contrast, and in defiance of its official title, the Meiji Restoration was a wholesale reform initiative driven in large part by an acknowledgment that the traditional social, political and economic organization of Japanese society was inadequate to deal with the modern challenges of adopting Western technologies and methods of production. Based on our hypothesis, it was driven by an eventual recognition that Western technologies and institutional organizations involved a degree of superiority that was significantly more advanced than those in Japan and, thus, that their adoption at the expense of Japanese traditional ways were worth their risk. To put things in the context of our model, the $\Delta G$ involved with Western technologies by the middle of the 19th century was significantly and apparently large relative to their $\Delta g$ for the Japanese to be willing to adopt them. In the words of Allen (1981, pp. 32, 33):

The Restoration Government recognized that Japan's military weakness and her economic backwardness might make her easy spoil of Western Powers and it judged that the rapid adoption of Western methods in war and industry could alone enable her to retain her independence and secure the abrogation of the 'unequal treaties'. The changes affected by the Government in social, industrial and commercial organization were as important as those in finance and politics. Most of the remaining restrictions on freedom of movement and enterprise that had been a legacy of the old regime were abolished. 
Further along the same lines, Duus (1976, pp. 74, 75) leaves little doubt that, while it was far from a cohesive block that had popular support, the goals of the Restoration Government were progressive and revolutionary:

The Western cannon and gunboats that had so agitated [the reformers] in the first place were quite visible. Their goals were very few and very simple, set forth in the Imperial Oath of 1868. This document committed the new government to convocation of an assembly and "public discussion" on matters of state, unity of "all cases high and low" in promoting the national welfare, abandonment of "absurd customs of olden times" and conformity to the "principles of international justice" and an effort at "seeking knowledge from all over the world." The basic issue over which differences arose was the problem of how much of the old society had to be jettisoned in order to strengthen the foundations of the Imperial polity. A minority of officials believed in a literal restoration of the monarchial way with direct rule by a divine priest-monarch, but their ideas did not prove persuasive.

The key features that emerged as marks of the Meiji Restoration were the consolidation of political authority and power with the central government; the conscription law as the basis of the modern Japanese military (paving the way for the eventual fall of the samurai); an active industrial policy funded, in large part, by a more efficient tax collection system made possible by the greater powers of the centralized government; and, last but not least, the introduction of a system of universal education (Duus 1976, pp. 76-86; Allen, 1981, p. 2).

The transformative nature of the Meiji Restoration was best manifested in the degree to which the intellectual elites began to study and analyze the ways of the West. Turning, once again, to Duus (1976, p. 87):

Since the 1850s the number of Japanese, usually samurai, sent abroad by bakufu or domain governments to studying the West had grown slowly but steadily. There were also many, coming out of the rangaku tradition, who avidly learned about the West through books without leaving Japan. In contrast to earlier Dutch scholars, this new group of Western experts was more interested in the society, laws, institutions, and philosophy of the West. The new Western experts emerged as the new intellectual elite in the 1860s and 1870s, replacing the old-style Confucian scholars as the critics and arbiters of social ideas. Through their translations and other writings detailed knowledge of the Western world diffused to the educated classes.

Recall that, based on the version of our model we presented above, formal education is the channel through which individuals' ideological beliefs could be updated to be more in line with a changing technological and institutional environment. Alternatively, we noted that formal education could be the channel through which existing and long-established beliefs would be propagated (a case which we shall discuss further below). And, based on our theoretical framework, recall that a stronger emphasis on the intergenerational propagation of existing beliefs is an important feature of conservative movements.

In this context, an interesting feature of Japanese history over the relevant timespan is the changing function and effect of education on social and institutional reforms. In particular, the education system was used explicitly as the medium through which the Confucian philosophy (ideology, in our parlance) was intergenerationally transmitted during the Tokugawa period when, as we discussed earlier in this section, the reforms had a clear conservative bend. We turn to Jansen (2000, p. 243) who elaborates on the nature of educational reforms during the Tansei era of the Tokugawa Shogunate: 
Sadanobu, a student of Confucianism, was particularly intent on ways to tidy up the educational and intellectual scene. The "Kansei prohibition" of dissident teachings proclaimed for the first time that Chu Hsi Confucianism was the orthodox teaching. Once in power, [Sadanobu] was concerned with order and convinced that the growth of competing philosophical thoughts created confusion. From this came the proscription of heterodoxy (igaku no kin) of 1790. "Novel doctrines" of recent times, he decreed, threatened the order of the realm; there was to be a "return" to a central doctrine.

By contrast, one of the most significant achievements of the Meiji era was the expansions in and the changing content of formal education and its interplay with other Meiji transformations in the institutional and economic realms. As Allen (1981, pp. 2, 3) states:

There can be little doubt that, from the outset of the modern era, the educational attainments of the Japanese did much to facilitate the communication of new ideas and technical methods. What is more, the ground had been prepared for further advances. The introduction of a system of universal education early in the Meiji era was a logical step forward and was accepted as such by the Japanese people. Throughout the modern period education, both general and technical, occupied a prominent place in the policies of successive Governments, and the proportion of the national income spent on it remained high in comparison with that of most other countries. In early Meiji times about one-third of the local authorities' expenditure went on education and this proportion did not change significantly throughout the era. It is now accepted by Japanese and foreign scholars alike that this investment in education was highly productive.

Once we introduce below the extension of our model where formal education serves as the channel of intergenerational belief or ideological transmission, we shall return to the Japanese case. In doing so, we will verify how, due to its changing content and function, formal education remained important when reforms in Japan were both conservative and when they were not.

\subsection{Qing China}

As our final historically relevant case, consider Qing China (1644-1912), which presents a particularly illuminating example of a "conservative revival" in response to foreign technological and institutional innovations. Prior to the Qing, it was not obvious that the West had pulled ahead economically and technologically. Indeed, prior to the fifteenth century, China far surpassed Europe in technological capability. In this period, the transfer of technologies overwhelmingly flowed from East to West-inventions such as paper, the compass, printing, gunpowder, iron plow, blast furnace, water clock, crossbow, and trebuchet were made in China centuries before their adoption in Europe (Mokyr 1990). However, by the dawn of the sixteenth century, numerous Western European technologies surpassed that of China. The observation led Mokyr (1990, p. 209) to argue that "the greatest enigma in the history of technology is the failure of China to sustain its technological supremacy." Chinese time-measuring technologies, ocean shipping, and block printing (as opposed to movable type) are examples of technologies in which China had reigned supreme for centuries

but fell behind Europe by 1500 CE. In spite of China's head start in knowledge of explosives, European military technology was far superior to anything found in China by the dawn of the sixteenth century (Needham 1986). When the Portuguese reached China's shores in 1514, the superiority of European muskets and cannons was apparent to all, and the Chinese rapidly adopted these weapons (Cipolla 1965; Hacker 1977). 
Like the Ottomans, the Ming (1368-1644) and Qing were quick to see the benefits of European military technology. In the sixteenth century, the Ming adopted much of what the West offered. However, also like the Ottomans, the Chinese adoption of Western techniques was largely confined to military innovations and weaponry, not economic or fiscal institutions. Even in the case of military technologies, the Qing emperors imposed severe limits on trade with the West. For example, the flintlock musket completely displaced previous types of muskets in Europe by 1725, but, as Needham (1986, p. 465) notes, "there seems to have been no flintlock period [in China] ... because of military conservatism." Moreover, numerous Western observers noted that, as late as 1850, the Chinese were using sixteenth-century weaponry-gunpowder weapons were limited to matchlocks and cannons that were similar to sixteenth and seventeenth century European models. Meanwhile, European military technology had advanced rapidly, and by mid-century technologies included caplock rifled muskets and shell guns (Hacker 1977). It was not until the mid-nineteenth century that China modernized its military technology, rapidly accepting Western technological advances in the face of the Taiping Rebellion (1851-1864) (Needham 1986; Mokyr 1990).

It was in the face of two contemporaneous crises - the rapid decimation of Chinese forces by the British in the First Opium War (1839-42) and numerous internal revolts, with the Taiping Rebellion being the most bloody and dangerous to the regime's future - that the Qing realized the need to modernize their economy and military. Revenues were too low to contain further rebellion (Ma and Rubin 2017), while the Qing faced an existential crisis of European domination that was temporarily relieved by their acquiescing to humiliating trade deals that gave Westerners extraordinary commercial powers within China. The adoption of Western institutions would have offered a solution to China's relative stagnation; politically constrained rulers, like those of the leading European powers, could have raised much more tax revenue and issued sovereign debt, while opening up markets and reducing arbitrary powers of government officials would have encouraged the adoption of techniques and technologies. It was unquestionable that Western economic and political institutions were more efficient than Chinese ones by the mid-19th century.

In the terms of our model, the potential $\Delta G$ available to the Qing was large if institutions and ideologies more commensurate with the improved technologies were adopted. But it was also highly uncertain how such institutions would interact with previously established Chinese institutions - ones that had served generations of Chinese rulers very well in the past. The most important of these institutions was the bureaucracy, with its grounding in Confucian ideals. Bureaucrats were the primary tax collectors, dispensors of law and order, chief instruments of peasantry control, and legitimizers of the state. The bureaucracy was by nature a conservative group, as it was tasked with providing stability rather than technological or economic improvement (Fei 1953; Wright 1957, p. 60-63; Chesneaux and Needham 1964, p. 593; Cipolla 1965; Mokyr 1990, p. 235-37). The ideal Confucian political system was based on an ethic of "enduring value, true and right for all men in all ages" (Wright 1957, p. 2) - precisely the type of conservatism we have in mind in our description of a "conservative revival."

Would the adoption of Western institutions have undermined the traditional bureaucracy? If it had, would this in turn have undermined the foundations of the Qing state? Wright (1957, p. 174-5) thinks this is likely: "[Qing] leaders were as little interested in modernizing the Chinese economy as they were in encouraging the commercial elements in the traditional economy. Their aim was the restoration of the old order, and they were intelligent enough to see that most of the new Western techniques for speeding production and distribution and increasing consumption were certain to disturb its stability." In the terms of model, the variance of institutional adoption, $\Delta g$, was large. In such a setting, our model predicts that a conservative revival may arise. 
The Qing responded to these crises with a set of policies known as the "Tongzhi Restoration" (1862-74), a period in which modernizing policies were enacted. These policies were implemented via the old, conservative bureaucratic institutions, led by scholars steeped in conservative Confucian ideology (Wright 1957). Instead of adopting Western governance, fiscal, or tax-collecting institutions, the Qing attempted to apply practical or rational Western knowledge without adopting the Western institutions that made this knowledge useful in the first place. According to Wright (1957, p. 63), "Restoration statesmen had no desire to create a new society. They wanted to restore a society that they confidently believed had been based on immutable truth and that could therefore, with adjustments, flourish in any age." For example, in order to deal with diplomacy with the European powers, the Qing government simply grafted a modern foreign relation office onto the bureaucracy, rather than removing the bureaucracy from foreign relations altogether (Wright 1957, p. 8). ${ }^{25}$ Hence, instead of seeking knowledge of the technological revolution occurring in Europe, the Chinese elites remained engrossed in preparing for the civil service exams based on knowledge of Chinese classics (Ma 2004). This "borrowing" of Western know-how and technology but not institutions is summarized nicely by Wright (1957, p. 1):

Chinese conservatism, ... aimed at the preservation of the Confucian, rationalist, gentry, and nonfeudal strains of pre-Taiping and pre-Opium War Chinese society. Chinese conservatives, unlike Chinese radicals, have not been interested in Western political or philosophical ideas. When they have been interested in the West at all, their interest has been solely in terms of the famous formula: 'Chineses learning as the basis; Western learning for practical use.'

A key element of the Restorations was the so-called "Self-Strengthening Movement", which discouraged private enterprise, disparaged commerce and foreign trade, emphasized agriculture above all other forms of economic activity, encouraged frugality, and discouraged investment in infrastructure in favor of "traditional" handicrafts (Wright 1957, ch. 8-9). As a result, private modern industry had no legal status in China until the 20th century (Brown 1979; Ma 2004). These policies in turn resulted in the loss of leadership in one of China's most important industries, sericulture (silk production) to Japan, whose Meiji government implemented Western reforms strongly encouraging private enterprise (despite its negative effects on traditional manufacturers) and important infrastructure such as the telegraph (Ma 2005). As Ma (2004, p. 374) notes, "the attitude of the Self-Strengthening Movement toward private initiatives in the modern sector ranged from indifference to hostility and displayed little interest in supplying modern public goods: in most cases, this movement was even opposed to private efforts to build public infrastructure such as railroads and inland steam shipping."

The Qing responses to Western advancement and its own internal troubles is a particularly straightforward example of what we mean by a society undergoing a "conservative revival". In the face of a rapidly changing world - a world that was obviously much more efficient than the world of previous Chinese glorythe Qing refrained from adopting the institutions that were responsible for Western economic success. The uncertainty related to how Western institutions, ideologies, and technologies would interact with prevailing Chinese institutions and ideological beliefs, both of which were steeped in a Confucian ethic that was often inconsistent with Western ideals, discouraged the Qing from adopting Western advancements despite very clear evidence that they were more efficient. It was only after China's failure to modernize became all the more obvious during the Sino-Japanese War (1894-95) that the failure of the empire's bureaucrats and

${ }^{25}$ It should be noted that the introduction of a modern foreign relations office was one of the most successful endeavors of the era, as it resulted in numerous accomplished diplomats and better foreign relations for China (Wright 1957, p. 8). 
leaders to grasp the obvious became inevitable: China had fallen behind. After all, the Westernizing Meiji reforms that Japan had recently undertaken had clearly enabled their humiliating victory over China. In this context, the Chinese finally considered major institutional changes. By then, however, it was too late; the Qing dynasty was on its last legs and would collapse in 1912.

\section{Extension: The Ruler's Optimal Ideology}

\subsection{Dynamics with Ruler having a Preferred Ideology}

Thus far, we constructed the model to show a "lower bound scenario" under which a conservative revival can arise. According to our formulation, the ruler has incentive to maximize the welfare of the citizenry and adjust institutions accordingly. Hence, rulers consider the positive effect of their institutional choice on the society's prevalent ideology. However, if the role of ideology is to help individuals make generalizations about the complex environment within which they operate, it is easy to imagine the ruler having an optimal ideology, $D^{R} \in \mathbb{R}^{+}$, which lends it political legitimacy and justifies its rule. Historical examples of such ideology include the "divine right of kings" doctrine employed by the English Stuart dynasty and Louis XIV of France, the Mandate of Heaven claimed by numerous Chinese emperors, or various Islamic doctrines supporting rulers who "act consistent with the faith" (Greif and Rubin 2015; Ma and Rubin 2017; Rubin 2017). These ideologies may affect or be affected by the institutional and technological environment of the society.

To address the possibility, we consider a minimal alteration to the Ruler's utility function. In this version of the model, the further the deviation in the society's prevalent ideology is from the Ruler's legitimizing ideology, the lower the Ruler's survival probability. We therefore interpret $D^{R}$ as the ideological basis for legitimacy in the Ruler's society (Greif and Rubin 2015), with any deviations from $D^{R}$ undermining the Ruler's legitimacy (and hence its capacity to stay in power). We operationalize this update to the model by having the Ruler maximize:

$$
U_{t}^{R}=\sum_{j=t}^{\infty}\left[\delta \frac{1}{1+\left(D_{t}^{o}-D^{R}\right)^{2}}\right]^{j-t} E\left[\tau y_{j}-c\left(I_{j}\right) \mid s_{j}^{o}, s_{j}^{R}\right],
$$

In other words, when $D_{t}^{o}=D^{R},(7)$ is the same as the Ruler's utility function laid out previously in equation (2). As $D_{t}^{o}$ diverges from $D^{R}$, the probability that the Ruler stays in power decreases. Note that deviations in either direction decrease the Ruler's survival probability. This is consistent with the idea, for instance, that the type of ideology that legitimates a democratically elected leader would not work to legitimate a tribal leader, while the tribal ideology that legitimates the leader would be useless in a democracy.

Assuming that the rest of the model is the same as in Section 2, the reaction function of the Ruler is implicitly defined by the first-order condition of the optimization problem described in equation (7):

$$
\frac{\tau \delta}{1-\delta}\left[\frac{1}{1+\left(D_{t}^{o}-D^{R}\right)^{2}}\right] \frac{\partial E\left(A_{t}\right)}{\partial I_{t}}-c^{\prime}\left(I_{t}\right) \leqslant 0,
$$

where $\partial E\left(A_{t}\right) / \partial I_{t}$ is still given by $(5)$.

Hence, the Ruler's reaction function, denoted $\bar{I}_{t}^{\prime}\left(\bar{e}_{t}\right)$, is augmented from the one derived in Section 2.3, $\bar{I}_{t}\left(\bar{e}_{t}\right)$, while the reaction function of the old agent, denoted $\bar{e}_{t}^{\prime}\left(\bar{I}_{t}\right)$, is the same as in Section 2.3. $\bar{I}_{t}^{\prime}\left(\bar{e}_{t}\right)$ differs from $\bar{I}_{t}\left(\bar{e}_{t}\right)$ in that, for any given $e_{t}$, the Ruler chooses a level of $I_{t}$ that pulls ideology closer to $D^{R}$. 
As $D_{t}^{o}$ diverges from $D^{R}$, the ruler's survival probability diminishes, and it this has incentive to invest in less (more) institutions in order to drive down (up) the agent's choice of ideology when $D_{t}^{o}>D^{R}\left(D_{t}^{o}<D^{R}\right)$. In other words, for any $e$ that implies $D_{t}^{o}>D^{R}$, the ruler chooses a lower value of $I_{t}$, while for any $e$ that implies $D_{t}^{o}<D^{R}$, the ruler chooses a higher value of $I_{t}$.

More importantly, the equilibrium reaction to the technology shock with be different under the present specification. When $D_{t}^{o}<D^{R}$ (that is, the Ruler's preferred ideology is more advanced than society's ideology) the Ruler responds to a shock by choosing more advanced institutions than it did under the specification presented in Section 2. Hence, there is a smaller part of the parameter space over which a conservative revival occurs. In the more common case, where $D_{t}^{o}>D^{R}$, the Ruler responds to a shock by choosing less advanced institutions than it did under the specification presented in Section 2. Hence, there is a larger part of the parameter space over which a conservative revival occurs.

On the one hand, this result should not be surprising; if the Ruler has incentive to discourage (encourage) ideological updating, changes in ideology should occur less (more) in equilibrium. But the mechanism through which this occurs is not obvious. Our model suggests a mechanism: the complementarity between institutions - which the Ruler affects - and ideology. In this specification, the Ruler has the capacity to indirectly affect ideology through its choice of institutions. In what follows, we tease out the implications of the model when the Ruler can directly affect ideology via public education.

\subsection{Dynamics with Public Education as the Indoctrination Medium}

Thus far, we assumed that the ideological intergenerational transmission mechanism was time spent between the parent and the child outside of school. In what follows, we consider an alternative version of our model where, as we discussed earlier, public education is the channel of ideological transmission intergenerationally (Lott 1990, 1999; Cantoni et al. 2017).

Keeping the extension laid out in the previous section, assume that a young agent receives ideology $D^{R}$ for "free" (i.e., without parental investment). On the other hand, in order to equip their children with ideological beliefs potentially more in line with the existing state of technologies, parents have to undertake costly investment in the education of their offspring beyond schooling offered publicly for free. Hence, we augment the interpretation of the variable $e_{t} \in[0,1]$ as the fraction of education received free via public schooling, with the residual $1-e_{t}$ the costly investment in private education. A slightly amended intergenerational ideological transmission process yields $D_{t}^{y}=\left(1-e_{t}\right) E\left[G_{t+1}\right]+e_{t} D^{R}$.

In this version of the model, the Ruler maximizes (7), as before, while the old agent maximizes (3) subject to $\left(1-e_{t}\right)+c_{t} \leq(1-\tau) y_{t}$. Hence, the Ruler's first order condition remains the one expressed in inequality (8), while the old agent's first order condition is:

$$
\begin{gathered}
-\frac{1}{(1-\tau) A_{t}-e_{t}}+\frac{p \beta \lambda\left(D^{R}-E\left[G_{t}\right]\right)\left[\left(1-e_{t}\right) E\left[G_{t}\right]+e_{t} D^{R}\right]^{\theta-1}}{\alpha(G+g)^{\theta}+\beta\left(\left(1-e_{t}\right) E\left[G_{t}\right]+e_{t} D^{R}\right)^{\theta}+(1-\alpha-\beta)\left(I_{t}\right)^{\theta}} \\
+\frac{(1-p) \beta \lambda\left(D^{R}-E\left[G_{t}\right]\right)\left[\left(1-e_{t}\right) E\left[G_{t}\right]+e_{t} D^{R}\right]^{\theta-1}}{\alpha(G-g)^{\theta}+\beta\left(\left(1-e_{t}\right) E\left[G_{t}\right]+e_{t} D^{R}\right)^{\theta}+(1-\alpha-\beta)\left(I_{t}\right)^{\theta}}
\end{gathered}
$$

Taking equations (7) and (9) at equality implicitly defines two reaction functions, denoted $I_{t}^{*}\left(e_{t}\right)$ and

$e_{t}^{*}\left(I_{t}\right)$, that characterize the intra-temporal equilibrium of this economy, with $\bar{I}_{t}^{*}\left(\bar{e}_{t}\right)$ and $\bar{e}_{t}^{*}\left(\bar{I}_{t}\right)$ denoting an equilibrium. Note that $D_{t}^{o} \geq D^{R}$ in equilibrium. Agents would never take on a costly investment in ideology when one with higher returns is available for free.

The case where $E\left[G_{t+1}\right] \leq D^{R}$ is trivial. Old agents will let public schools indoctrinate their children for 
free (i.e., choose $e_{t}=1$ ), and the Ruler has a survival probability of 1 and chooses institutions to optimize its objective function at $D_{t}^{o}=D^{R}$. The more interesting case is $E\left[G_{t+1}\right]>D^{R}$. Here, old agents may choose a positive amount of "private" education (i.e., $e_{t}<1$ ), even in the steady state. This is unlike the previous model, were ideology accumulated over time. If any generation invests nothing in private education $\left(e_{t}=1\right)$, ideology reverts back to $D_{t}^{y}=D^{R}$.

As before, consider a technology shock of magnitude $\Delta G$, with a corresponding variance shock $\Delta g$. The Ruler's response function $\bar{I}_{t}^{*}\left(\bar{e}_{t}\right)$ is even less responsive than in the previous section for any given $\{\Delta G, \Delta g\}$ combination. Under the current specification, increasing $I_{t}$ encourages ideological beliefs to move further from the Ruler's optimal ideology than in the previous section, since the agent's default ideology is $D_{t}^{y}=D^{R}$ (rather than $D_{t}^{y}=D_{t}^{o}$ ). Hence, the ruler is incentivized to choose a weakly lower level of institutions than it did following a shock of the same magnitude under the specifications of the previous section.

On the other hand, the shock may encourage a greater response in costly education in this specification than it did under the previous ones. If $D^{R}$ is smaller than the pre-shock ideology of the old agent $\left(D_{t}^{o}\right)$ in the previous model, then there is more to gain on the margin for the agent to investing in $1-e_{t}$ for its offspring. This is because the "default" ideology ( $D^{R}$ in this case, $D_{t}^{o}$ previously) - that is, the one which is given to offspring if investment is zero-is smaller, and there is thus more to gain on the margin after a shock increases the return to higher ideology. ${ }^{26}$

These two effects are therefore offsetting. Under the present specification, there is less incentive for the Ruler to update institutions, while there may be more incentive (when $D^{R}$ is sufficiently small) for the old agent to invest in education. Which effect is stronger depends on just how small $D^{R}$ is relative to $E\left[G_{t+1}\right]$. When $D^{R}$ is sufficiently close to $E\left[G_{t+1}\right]$, the parameter space over which a conservative revival arises is greater in the current specification than it was in previous specifications. This is because the difference in the agent's reaction function is minimal between specifications, while the Ruler has much less incentive to invest in institutions in the current specification. On the other hand, when $D^{R}$ is sufficiently small, a conservative revival is less likely to arise under the current specification. This is because agents' ideologies are so far away from the optimal level that there is more incentive on the margin to increase ideology in response to a shock.

The interpretation of this result is straight-forward. If the Ruler can indoctrinate the citizens with an ideology that favors itself, it will be able to do so as long as the real world conditions, $E\left[G_{t+1}\right]$, are not too far removed from this ideology. However, when a shock occurs that sets $E\left[G_{t+1}\right]$ sufficiently far away from $D^{R}$, citizens will choose some positive level of private education, leading to a change in ideology away from the Ruler's desired one. This insight helps explain the reforms that eventually took place in the Ottoman Empire and Meiji Japan, after the difference in Western institutions and technologies and the prevailing ones in these regimes were too obvious to ignore.

An additional corollary of our extended model is the debilitating impact of new technologies on the stability of political regimes that rely on some specific ideology and an indoctrination apparatus designed to nourish such ideology. In our context, new technologies do not destabilize political regimes because they enable more efficient communication and coordination among the citizenry. ${ }^{27}$ They do so because updating their beliefs and ideologies is economically optimal for individuals, which makes it costlier for rulers to ensure that the prevalent ideologies do not stray too much from those that legitimize their rule.

In both Japan and the waning years of the Ottoman Empire, there is historical evidence and ample

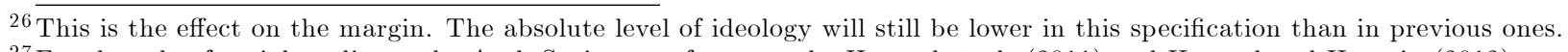

${ }^{27}$ For the role of social media on the Arab Spring, see for example, Howard et al. (2011) and Howard and Hussain (2012). 
anecdotal references that the functions and objectives of the public education systems were transformed as well. As we discussed in Sections 3.2 and 3.3 above, the Japanese and Chinese education systems were used explicitly as the medium through which the Confucian philosophy and its manifest ideologies were indoctrinated to the younger generations during the Tokugawa reforms and Tongzhi Restoration, both of which were inherently conservative (Jansen 2000, p. 243; Wright 1957). However, in the Japanese case, the subsequent Meiji era was very clearly and consistently characterized as one in which the expansion in and the changing content of formal education was the primary driver of other fundamental Meiji transformations in the institutional and economic realms (Allen 1981, pp. 2-3; Duus 1967, p. 89).

As for the late Ottoman era and the early Turkish Republic, the role of education as an indoctrination medium versus a scientific education medium is only slightly more muddled. The traditional Ottoman educational system centered around "the elementary mosque schools (mekteps), which gave rudimentary religious education to the masses, and the higher institutions of learning (medreses), which trained new members of the ulema [Islamic theological scholars] as well as others entering the Ruling Class," Shaw (pp. 132-33). After The Royal Tanzimat Decree of 1839 which, as we discussed above, aimed to progressively reform Ottoman society and institutions along Western cleavages, the educational system was intended to be reoriented toward an objective scientific emphasis. To that end, the General Education Regulation of 1869 (Maarif-I Umumiye Nizamnamesi) announced that primary education would be compulsory and free for all citizens (Gők 2007). This objective did not materialize before the empire disintegrated, however, and Ottoman education continued to harbor elements of religious and political indoctrination in deliberate attempts to protect and strengthen the crumbling empire. In the words of Mango (1999, pp. 15, 16):

Sultan Abdülhamit strengthened the bureaucratic Muslim clerical establishment and encouraged the building of mosques. He invested heavily in education, which combined religious instruction with new European learning. A network of secondary schools, divided into civil and military, and leading to specialized institutions of higher education, covered the empire. They were designed to train enlightened but pious civil servants and soldiers.

Only after the establishment of the Turkish Republic in 1923 was a major step taken toward universal secular education. With the 1924 Law on Unification of Education, "the national secular education system, fashioned on the Western European model, especially the French system, was established. By means of the law, all scientific and educational institutions were brought under [central control], and all kinds of religious educational and training institutions ceased to function," (Gők 2007). To be sure, Turkish education maintained a heavy dose of nationalist indoctrination put in the service of the young republic, as primary and secondary education textbooks were diligently and carefully crafted to unify a friendly narrative on Turkish nationalism, culture and history. Nevertheless, literacy rates, which were as low as ten percent, doubled within a decade, continuing to increase at a rapid clip thereafter. The secular, uniform and mandatory education laws helped to advance women's educational attainment and social freedoms at levels theretofore unseen in a Muslim society (Mango 1999, pp. 494, 533, 535).

\section{Conclusion}

In this paper, we propose a theoretical framework that seeks to explain why institutional reforms by themselves have historically not been the elixir of economic development. We emphasize the role of ideological 
beliefs in economic development, in particular, the interplay between new technologies, ideologies, and institutions.

According to our model, new technologies entail both risk and reward. When the risks of new technologies and uncertainties inherent in them dominate during times of rapid technological change, they can generate a conservative ideological backlash that puts a higher premium on traditional beliefs and values. In that case, we show that institutions will stagnate as well. Only when the superiority of new technologies outweighs their inherent risks does the pace of institutional change accelerate in conjunction with a more progressive ideology that deemphasizes traditional beliefs.

We visit five historical episodes from three countries: early Ottoman reform initiatives versus the Ottoman Tanzimat era, the Japanese Tokugawa reforms versus the Meiji Restoration and the Tongzhi Restoration in Qing China. All of these cases illustrate how the interplay between ideologies and institutional adaptation in the face of rapid technological progress influenced long-run economic outcomes. In these cases, we show how the societies' long-standing beliefs and ideologies were impediments to meaningful institutional reforms and how, when these societies were exposed to more sophisticated and advanced technologies with their inherent perceived risks, early reform attempts were fundamentally conservative in nature. And in all of these cases, we discuss how more wholesale institutional reforms only came on the back of clear evidence of the superiority of the technological advances. 


\section{References}

Acemoglu, Daron, and Matthew O. Jackson. 2016. "Social Norms and the Enforcement of Laws." Journal of the European Economic Association. Forthcoming.

Acemoglu, Daron, and James A. Robinson. 2000. "Political Losers as a Barrier to Economic Development." American Economic Review 90: 126-130.

Acemoglu, Daron, and James A. Robinson. 2006. "Economic Backwardness in Political Perspective," American Political Science Review 100: 115-131.

Alesina, Alberto and Paola Giuliano. 2015. "Culture and Institutions." Journal of Economic Literature 53(4): 898-944.

Alesina Alberto, Giuliano Paola, and Nunn Nathan. 2013. "On the Origins of Gender Roles: Women and the Plough." Quarterly Journal of Economics. 128(2): 469-530.

Algan, Yann and Pierre Cahuc. 2013. "Trust and Human Development: Overview and Policy Implications." in Handbook of Economic Growth, Philippe Aghion and Steven N Durlauf (Eds.). Vol. 1A.

Allen, G. C. 1981. A Short Economic History of Modern Japan. New York, NY: Saint Martin's Press.

Alston, Lee J., Marcus André Melo, Bernardo Mueller, and Carlos Pereira. Brazil in Transition: Beliefs, Leadership, and Institutional Change. Princeton: Princeton University Press.

Balla, Eliana and Noel D. Johnson. 2009. "Fiscal Crisis and Institutional Change in the Ottoman Empire and France." Journal of Economic History 69(3): 809-45.

Becker, Sascha O., Katrin Boeckh, Christa Hainz, and Ludger Woessmann. 2016. "The Empire is Dead, Long Live the Empire! Long-Run Persistence of Trust and Corruption in the Bureaucracy." Economic Journal 126(590): 40-74.

Bisin, Alberto, and Thierry Verdier. 2001. "The Economics of Cultural Transmission and the Dynamics of Preferences." Journal of Economic Theory 97: 298-319.

Bisin, Alberto, and Thierry Verdier. 2015. "On the Joint Evolution of Culture and Institutions." Working Paper.

Brown, Shannon R. 1979. "The Ewo Filature: A Study in the Transfer of Technology to China in the 19th Century." Technology and Culture 20(3): 550-68.

Buggle, Johannes. 2016. "Law and Social Capital: Evidence from the Cod Napoleon in Germany." European Economic Review 87: 148-175.

Cantoni, Davide, Yuyu Chen, David Y. Yang, Noam Yuchtman, and Y. Jane Zhang. 2017. "Curriculum and Ideology." Journal of Political Economy 125(2): 338-392.

Chaudhry, Azam, and Phillip Garner. 2006. "Political Competition between Countries and Economic Growth." Review of Development Economics 10: 666-682.

Chesneaux, Jean and Joseph Needham. 1964. "Science in the Far East from the 16th to the 18th Century." In: The Beginnings of Modern Science: From 1450 to 1850, René Taton (Ed.). New York: Basic Books. 
Cipolla, Carlo M. 1965. Guns, Sails, and Empires: Technological Innovation and the Early Phases of European Expansion 1400-1700. New York: Pantheon.

Coşgel, Metin M. and Thomas J. Miceli. 2005. "Risk, Transaction Costs, and Government Finance: The Distribution of Tax Revenue in the Ottoman Empire." Journal of Economic History 65(3): 806-21.

Coşgel, Metin M.; Thomas J. Miceli and Jared Rubin. 2012. "The Political Economy of Mass Printing: Legitimacy, Revolt, and Technology Change in the Ottoman Empire." Journal of Comparative Economics 40(3): 357-371.

Dale, Stephen F. 2010. The Muslim Empires of the Ottomans, Safavids, and Mughals. Cambridge: Cambridge University Press.

Dincecco, Mark. 2009. "Fiscal Centralization, Limited Government, and Public Revenues in Europe." Journal of Economic History 69(1): 48-103.

Duus, Peter. 1976. The Rise of Modern Japan. New York, NY: Houghton Mifflin Company.

Fei, Hsiao-Tung. 1953. China's Gentry: Essays in Rural-Urban Relations. Chicago: University of Chicago Press.

Gershman, Boris. 2016. "Long-Run Development and the New Cultural Economics." Working Paper.

Giuliano, Paola. 2007. "Living Arrangements in Western Europe: Does Cultural Origin Matter?" Journal of the European Economic Association 5(5): 927-52.

Giuliano, Paola and Nathan Nunn. 2016. "Understanding Cultural Persistence and Change." Harvard Universtity, mimeo.

Gők, Fatma. 2007. "The History and Development of Turkish Education." in Education in Multicultural Societies - Turkish and Sweden Perpectives, eds. Gök, F., Carlson, M. and Rabo, A.

Goldin, Claudia, and Lawrence F. Katz. 1998. "The Origins of Technology-Skill Complementarity." Quarterly Journal of Economics 113(3): 693-732.

Goldin, Claudia, and Lawrence F. Katz. 2008. The Race between Education and Technology. Cambridge, MA: Harvard University Press.

Gorodnichenko, Yuriy, and Gérard Roland. 2011. "Which Dimensions of Culture Matter for Long-Run Growth?" American Economic Review 101(3): 492-498.

Gorodnichenko, Yuriy, and Gérard Roland. 2016. "Culture, Institutions, and the Wealth of Nations." Review of Economics and Statistics forthcoming.

Greif, Avner. 1994. "Cultural Beliefs and the Organization of Society: A Historical and Theoretical Reflection on Collectivist and Individualist Societies." Journal of Political Economy 102(5): 912-950.

Greif, Avner. 2006. Institutions and the Path to the Modern Economy. Cambridge: Cambridge University Press.

Greif, Avner, and Murat Iyigun. 2013. "Social Organizations, Risk-Sharing Institutions and Industrialization." American Economic Review (P \& P), 103:3, 534-38, May. 
Greif, Avner, Murat Iyigun and Diego Sasson. 2012. "Social Institutions and Economic Growth: Why England and not China Became the First Modern Economy." Stanford University Working Paper.

Greif, Avner and Joel Mokyr. 2016. "Cognitive Rules, Institutions, and Economic Growth: Douglass North and Beyond." Journal of Institutional Economics 13(1): 25-52.

Greif, Avner and Jared Rubin. 2015. "Endogenous Political Legitimacy: The English Reformation and the Institutional Foundations of Limited Government." Working Paper.

Greif, Avner, and Guido Tabellini. 2017. "The Clan and the Corporation: Sustaining Cooperation in China and Europe." Journal of Comparative Economics: forthcoming.

Greif, Avner, and Steven Tadelis. 2010. "A Theory of Moral Persistence: Crypto-Morality and Political Legitimacy." Journal of Comparative Economics 38: 229-244.

Grosfeld, Irena, Alexander Rodnyansky, and Ekaterina Zhuravskaya. 2013. "Persistent Anti-market Culture: A Legacy of the Pale of Settlement and of the Holocaust." American Economic Journal: Economic Policy 5(3): 189-226.

Guiso, Luigi, Paola Sapienza, and Luigi Zingales. 2006. "Does Culture Affect Economic Outcomes?" Journal of Economic Perspectives 20(2): 23-48.

Guiso, Luigi, Paola Sapienza, and Luigi Zingales. 2008. "Social Capital as Good Culture." Journal of the European Economic Association 6(2-3): 295-320.

Guiso, Luigi, Paola Sapienza, and Luigi Zingales. 2016. "Long Term Persistence." Journal of the European Economic Association 14(6): 1401-1436.

Hacker, Barton C. 1977. "The Weapons of the West: Military Technology and Modernization in 19th-Century China and Japan." Technology and Culture 18: 43-55.

Haidt, Jonathan. 2012. The Righteous Mind: Why Good People Are Divided by Politics and Religion. (New York, NY: Pantheon Books).

Hourani, Albert. 1991. A History of the Arab Peoples. Cambridge: Harvard University Press.

Howard, Douglas A. 1988. "Ottoman Historiography and the Literature of 'Decline' of the Sixteenth and Seventeenth Centuries." Journal of Asian History 22(1) 52-77.

Howard, Philip N., Aiden Duffy, Deen Freelon, Muzammil Hussain, Will Mari, and Marwa Mazaid. 2011. "Opening Closed Regimes: What was the role of social media during the Arab Spring?' Project on Information Technology and Political Islam, Research, unpublished manuscript, University of Washington.

Howard, Philip N. and Muzammil M. Hussain. 2012. "Digital Media and the Arab Spring." In Liberation Technology: Social Media and the Struggle for Democracy (Eds.). Johns Hopkins University Press.

Imber, Colin. 2016. "Koçi Beg/Gördidjeli Kodja Mustafa Beg." Encyclopedia of Islam II (Brill).

İnalcık, Halil. 1973. The Ottoman Empire. New York: Praeger.

Iyigun, Murat. 2015. War, Peace and Prosperity in the Name of God. Chicago: University of Chicago Press. 
Iyigun, Murat, Naci Mocan and Ann Owen. 2001. "Ideology, Human Capital and Growth." Universtity of Colorado, Boulder, unpublished working paper.

Jansen, Marius, B. 2000. The Making of Modern Japan. Cambridge, MA: The Belknap Press of Harvard University Press.

Jha, Saumitra. 2013. "Trade, Institutions, and Ethnic Tolerance: Evidence from South Asia." American Political Science Review 107(4): 806-32.

Jost, J. John. 2006. "The End of the End of Ideology." American Psychologist, Vol. 61, No. 7, pp. 651-670; October.

Karaman, Kıvanç and Şevket Pamuk. 2010. "Ottoman State Finances in European Perspective, 1500-1914." Journal of Economic History 70(3): 593-629.

Karaman, Kıvanç and Şevket Pamuk. 2013. "Different Paths to the Modern State in Europe: The Interaction between Warfare, Economic Structure, and Political Regime." American Political Science Review 107(3): $603-26$.

Koyama, Mark, Chiaki Moriguchi, and Tuan-Hwee Sng. 2016. "Geopolitics and Asia's Little Divergence: A Comparative Analysis of State Building in China and Japan after 1850." Working Paper.

Kuran, Timur. 2011. The Long Divergence: How Islamic Law Held Back the Middle East. Princeton: Princeton University Press.

Laber-Warren, Emily. 2012. "Unconscious Reactions Separate Liberals and Conservatives." Scientifi American, September 1.

Lewis, Bernard. 1973. Islam in History. New York: Library Press.

Lewis, Bernard. 2002. What Went Wrong? The Clash between Islam and Modernity in the Middle East. New York: HarperCollins.

Lott, John R. Jr. 1990. "An Explanation for Public Provision of Schooling: The Importance of Indoctrination." Journal of Law E Economics 33(1): 199-231.

Lott, John R. Jr. 1999. "Public Schooling, Indoctrination and Totalitarianism." Journal of Political Economy 107(S6): 127-57.

Lowes, Sara, Nathan Nunn, James A. Robinson, and Jonathan Weigel. 2017. "The Evolution of Culture and Institutions: Evidence from the Kuba Kingdom." Econometrica: forthcoming.

Ma, Debin. 2004. "Why Japan, Not China, Was the First to Develop in East Asia: Lessons from Sericulture, 1850-1937." Economic Development and Cultural Change 52(2): 369-94.

Ma, Debin. 2005. "Between Cottage and Factory: The Evolution of Chinese and Japanese Silk-Reeling Industries in the Latter Half of the Nineteenth Century." Journal of the Asia Pacific Economy 10(2): 195-213.

Ma, Debin and Jared Rubin. 2017. "The Paradox of Power: Understanding Fiscal Capacity in Imperial China and Absolutist Regimes." Working Paper. 
Mango, Andrew. 1999. Atatürk: The Biography of the Founder of Modern Turkey. New York: The Overlook Press.

Mokyr, Joel. 1990. The Lever of Riches. Oxford: Oxford University Press.

Needham, Joseph. 1986. Science and Civilization in China, Vol. 5. Cambridge: Cambridge University Press.

North, Douglass. 1981. Structure and Change in Economic History. New York: Norton.

North, Douglass C. and Barry R. Weingast. 1989. "Constitutions and Commitment: The Evolution of Institutional Governing Public Choice in Seventeenth-Century England." Journal of Economic History 49(4): 803-32.

Nunn, Nathan. 2012. "Culture and the Historical Process." Economic History of Developing Regions 27(S1): 108-126.

Nunn, Nathan and Raul Sanchez de la Sierra. 2017. "Why Being Wrong can be Right: Magical Warfare Technologies and the Persistence of False Beliefs." American Economic Review: Forthcoming.

Nunn, Nathan, and Leonard Wantchekon. 2011. "The Slave Trade and the Origins of Mistrust in Africa." American Economic Review 101(7): 3221-52.

Pamuk, Şevket. 2004a. "The Evolution of Financial Institutions in the Ottoman Empire, 1600-1914." Financial History Review 11(1): 7-32.

Putnam, Robert. 1993. Making Democracy Work: Civic Traditions in Modern Italy. Princeton: Princeton University Press.

Rubin, Jared. 2011. "Institutions, the Rise of Commerce, and the Persistence of Laws: Interest Restrictions in Islam \& Christianity." Economic Journal 121(557): 1310-39.

Rubin, Jared. 2017. Rulers, Religion, and Riches: Why the West got rich and the Middle East did not. Cambridge: Cambridge University Press.

Rubin, Jared and Elira Karaja. 2017. "The Cultural Transmission of Trust Norms: Evidence from a Lab in the Field on a Natural Experiment." Working Paper.

Shaw, Stanford. 1976. History of the Ottoman Empire and Modern Turkey. Cambridge: Cambridge University Press.

Spolaore, Enrico and Romain Wacziarg. 2013. "How Deep are the Roots of Economic Development?" Journal of Economic Literature 51(2): 325-69.

Tabellini, Guido. 2008. "Presidential Address: Institutions and Culture." Journal of the European Economic Association 6(2/3): 255-294.

Tabellini, Guido. 2010. "Culture and Institutions: Economic Development in the Regions of Europe." Journal of the European Economic Association 8(4): 677-716.

Voigtländer, Nico, and Hans-Joachim Voth. 2012. "Persecution Perpetuated: The Medieval Origins of AntiSemetic Violence in Nazi Germany." Quarterly Journal of Economics 127(3): 1339-92. 
Wright, Mary C. The Last Stand of Chinese Conservatism: The T'ung-Chih Restoration, 1862-1874. New York: Atheneum. 


\title{
A Appendix: Extra Figures and Robustness Checks
}

\author{
FOR ONLINE PUBLICATION
}

Figure A1: Case II; $G=10, g=5$

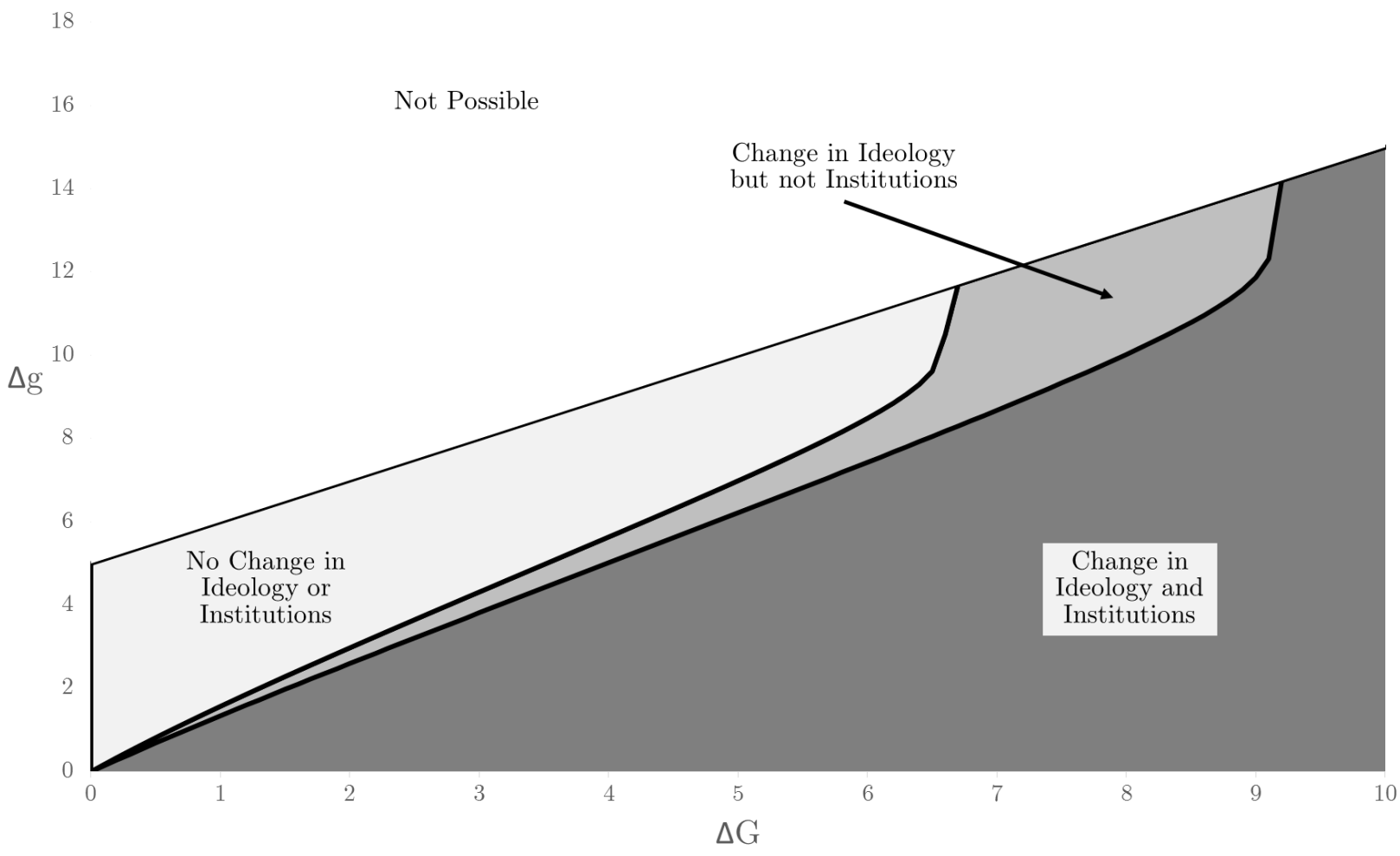


Figure A2: Case III: $G=10, g=5, p=0.60$

Not Possible

\section{4}

12

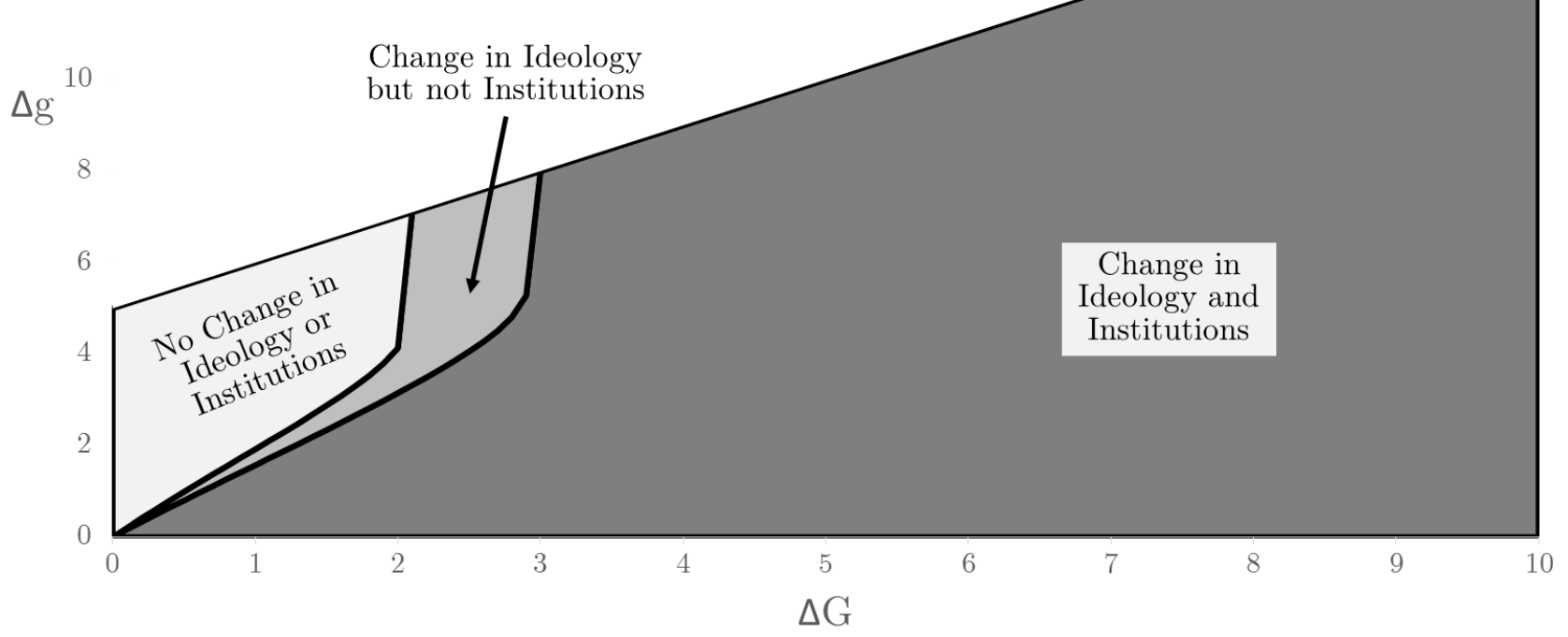


Figure A3: Case IV: $G=10, g=5, p=0.40$

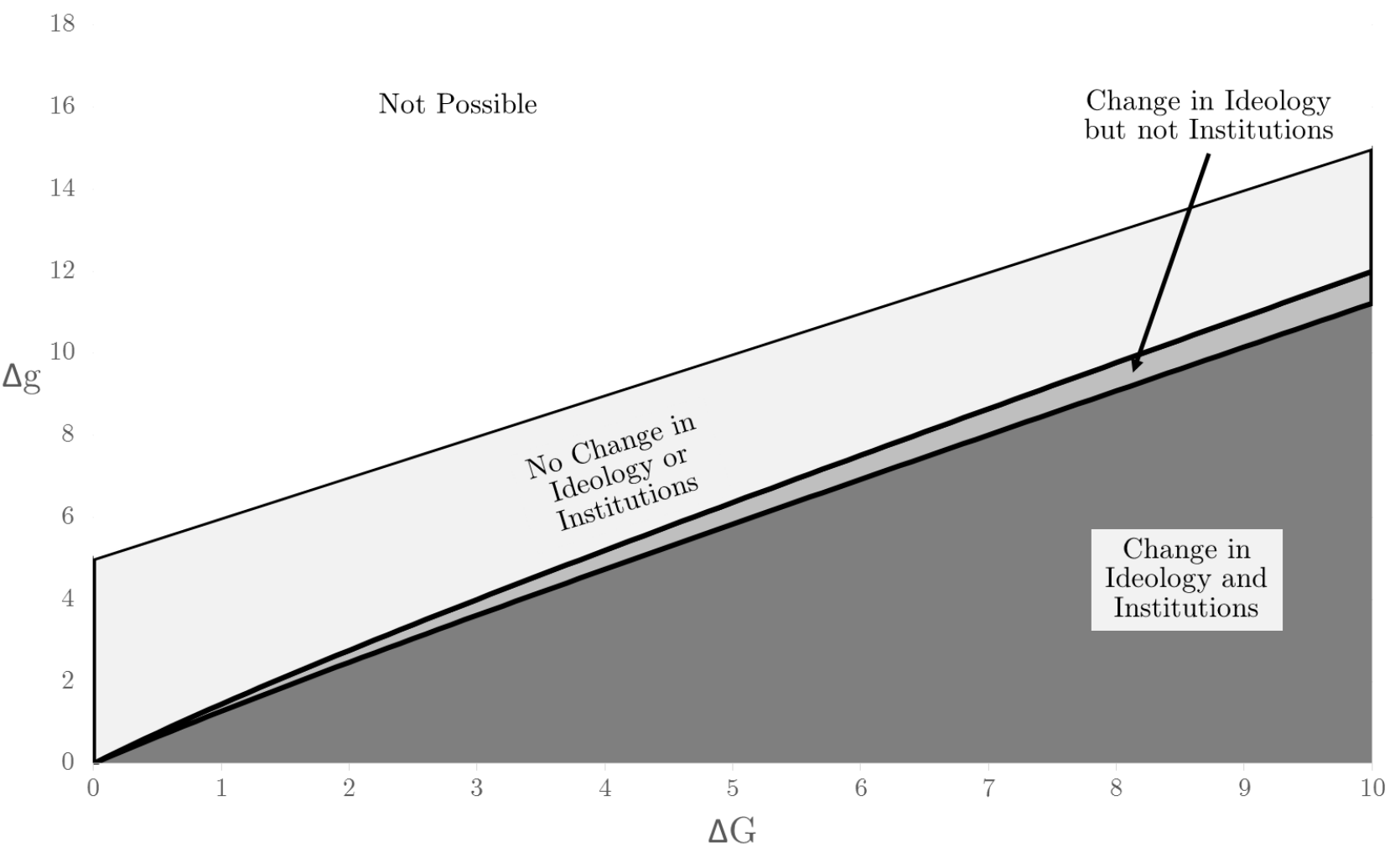


Table A1: Values for Numerical Simulations, Robustness Checks

\begin{tabular}{ccccccccc} 
Parameters & Case A1 & Case A2 & Case A3 & Case A4 & Case A5 & Case A6 & Case A7 & Case A8 \\
\hline \hline$\alpha$ & 0.3 & 0.3 & 0.3 & 0.3 & 0.3 & 0.3 & 0.3 & 0.3 \\
$\beta$ & 0.3 & 0.3 & 0.3 & 0.3 & 0.3 & 0.3 & 0.3 & 0.3 \\
$\theta$ & -6 & -6 & -6 & -6 & -6 & -6 & -6 & -6 \\
$\delta$ & 0.98 & 0.98 & 0.98 & 0.98 & 0.98 & 0.98 & 0.98 & 0.98 \\
$\tau$ & 0.1 & 0.1 & 0.1 & 0.3 & 0.3 & 0.1 & 0.1 & 0.1 \\
$\gamma$ & 1.2 & 1.2 & 1.2 & 1.2 & 1.2 & 1.2 & 1.2 & 1.2 \\
$\lambda$ & 0.5 & 0.5 & 0.5 & 2 & 0.5 & 0.5 & 0.5 & 0.5 \\
$p$ & 0.5 & 0.4 & 0.6 & 0.5 & 0.5 & 0.5 & 0.4 & 0.6 \\
\hline \hline
\end{tabular}

\begin{tabular}{ccccccccc}
\hline \hline \multicolumn{10}{c}{ Pre-Shock Technology } \\
$G$ & 10 & 10 & 10 & 10 & 10 & 20 & 20 & 20 \\
$g$ & 5 & 5 & 5 & 5 & 5 & 5 & 5 & 5 \\
\hline \hline & 2.83 & 2.55 & 3.10 & 2.87 & 2.87 & 5.74 & 5.45 & 6.03 \\
$\bar{D}_{0}$ & 3.35 & 3.03 & 3.65 & 7.12 & 4.10 & 6.61 & 6.29 & 6.92 \\
$\bar{I}_{0}$ & & \multicolumn{10}{c}{ Pre-Shock Steady State }
\end{tabular}


Figure A4: Ideological Transition Frontier, Cases A1-A8

\section{CASE A1}
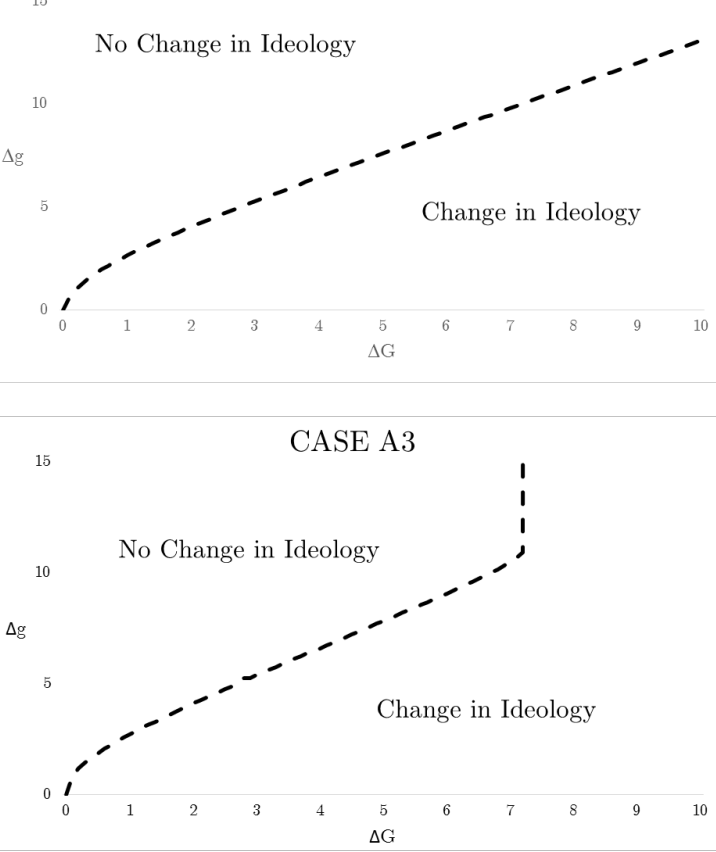

CASE A5
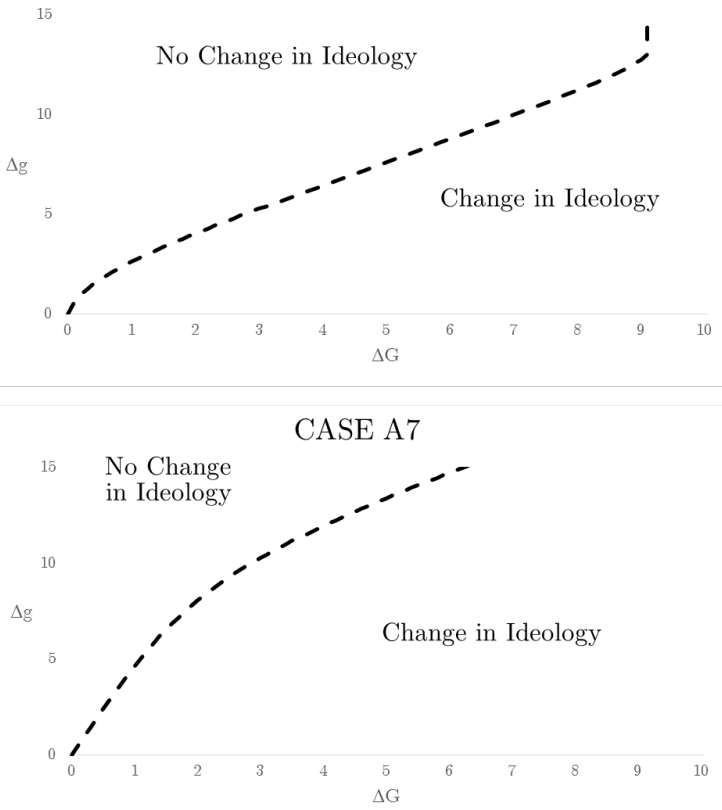

CASE A2
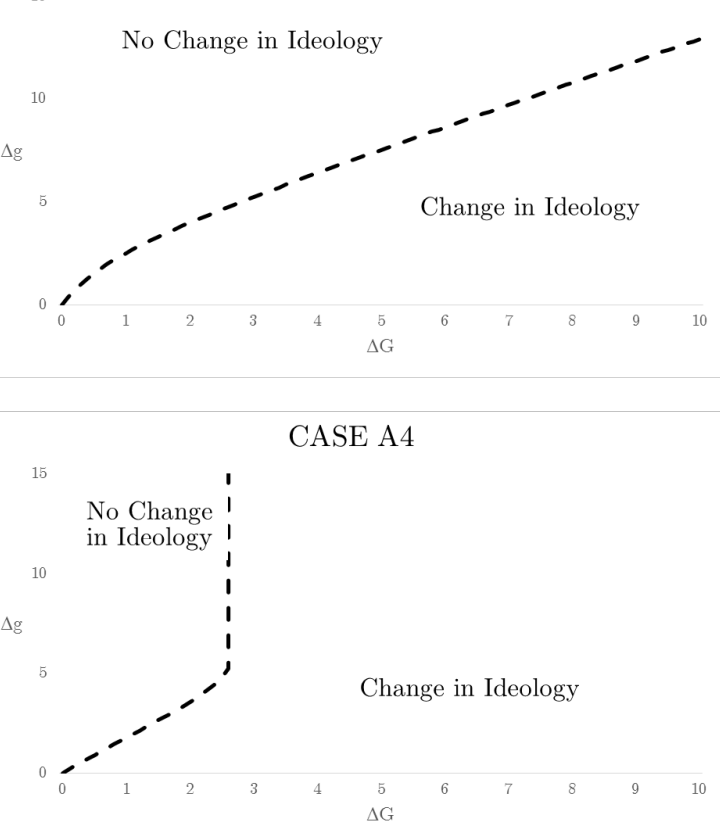

CASE A6
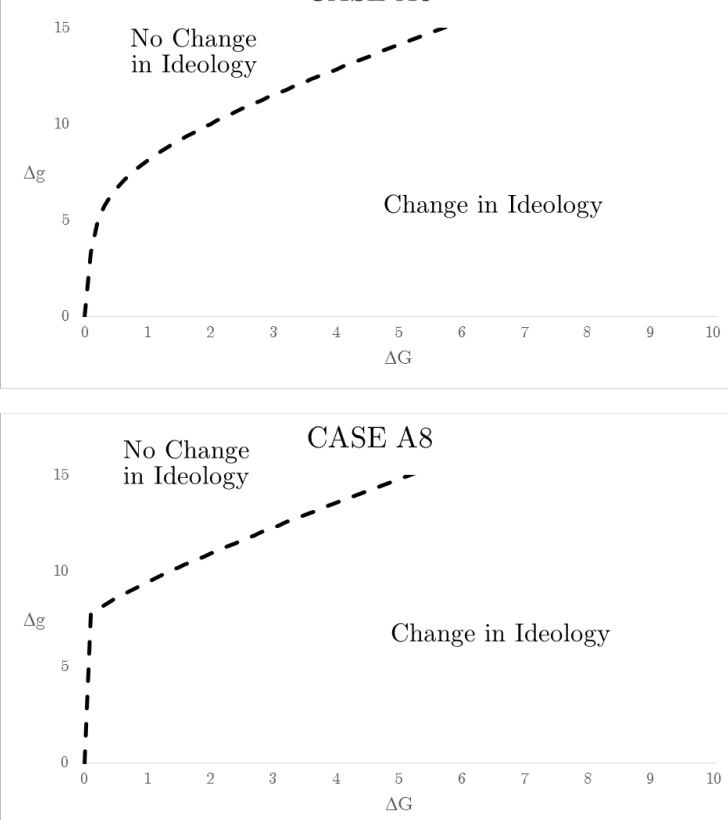